\title{
Discovering Viking America
}

\author{
J. M. Mancini
}

In 1874, Professor Rasmus Bjørn Anderson of the University of Wisconsin offered the following unapologetic assessment of his ancestors, the Norwegians. "Yes," he wrote, "the Norsemen were truly a great people! Their spirit found its way into the Magna Charta of England and into the Declaration of In[d] ependence in America. The spirit of the Vikings still survives in the bosoms of Englishmen, Americans and Norsemen, extending their commerce, taking bold positions against tyranny, and producing wonderful internal improvements in these countries." provides the template for an immigrant historical literature that would span two centuries and two nations and would provide Scandinavians with a powerful strategy for the attainment of ethnic autonomy. Arguing that the Norsemen had discovered America nearly five centuries before Columbus, Anderson rejected more familiar immigrant literary strategies of assimilation or resistance and attempted to win a place for New World Norwegians by rewriting the very foundation myths of the American nation. ${ }^{2}$ By dis-

\footnotetext{
This project was supported by grants from the Department of Archives and Special Collections of the Elizabeth Dafoe Library, University of Manitoba; the Minnesota Historical Society; and Mount Royal College; and by the efforts of numerous friends and colleagues. I would also like to say a special word of thanks to Cathy Jurca.

1. Rasmus B. Anderson, America Not Discovered by Columbus: An Historical Sketch of the Discovery of America by the Norsemen in the Tenth Century (1874; Chicago, 1877), p. 63; hereafter abbreviated $A$.

2. There is a vast and fraught literature on the question of the immigrant cultural response to relocation. In the main, historians have set up this problem as a dialectic between assimilation and resistance, exemplified at either pole by Oscar Handlin's seminal The Uprooted (1951; Boston, 1973), and John Bodnar's The Transplanted: A History of Immigrants in Urban America (Bloomington, Ind., 1985). Even as "resistance" emerged as the dominant paradigm in the 1980s (seen, for example, in the hostile response to Richard Rodriguez's Hunger of Memory: The Education of Richard Rodriguez [Boston, 1982]), however, it proved to be unsustainable as a fit-all 
covering Viking America, Anderson was able, at the most vulnerable moment in the trajectory of acculturation, to fashion an immigrant history of his own and to script his group's entry onto the American stage.

Anderson himself was the beneficiary of an earlier Norwegian immigrant strategy that began to come to fruition in his own generation: the choice to move west rather than to settle in the urban industrial centers of the east. This decision placed Norwegian immigrants at the physical and political margins of the nation. Within this frontier context, which had the added benefit of seeming less threatening to the native born than the wards that bore America's urban immigrant politicians, Norwegian Americans enjoyed their first major political successes. Indeed, their ascent within the American power structure in the second generation was predicated not on their assimilation (as frontier theorists might have expected), as much as on their ability to consolidate the political margin. In particular, they proved adept at using ethnic bloc voting, enabled by the unusually high percentage of immigrants and relative lack of an entrenched power structure in the upper Midwest (fig. 1) to gain access to local, state, and national politics. Thus, it is no accident that Minnesota congressman, governor, and senator

theory, and signs of its instability mark much of the literature of the past two decades. Both Roy Rosenzweig, Eight Hours for What We Will: Workers and Leisure in an Industrial City, 1870-1920 (New York, 1983) and David Roediger, The Wages of Whiteness: Race and the Making of the American Working Class (London, 1991), two otherwise brilliant works, stumble on their inability to reconcile a desire for (authentic) immigrant resistance to the reality of assimilation. Thus when Rosenzweig's makers of ethnic saloons, fraternal associations, and foreign-language presses are inevitably ground down into a homogenized army of cinema-watching, motorcar-driving robots, and assimilation turns Roediger's music-sharing, race-mixing, land-loving Irish into psychologically damaged, race-baiting Irish Americans, both seem to suggest that this represents a falling away from immigrants" "true" selves. This problem is not limited to contemporary scholarship but is rooted in historical analyses of immigration and assimilation, such as Randolph Bourne's seminal essay “Trans-National America," in War and the Intellectuals, ed. Carl Resek (New York, 1964), pp. 107-24. Indeed, it is possible that Bourne furnished contemporary immigration scholarship with one of its central ironies: its insistence, on the one hand, on the "constructedness" of ethnicity — seen, for example, in Mary Waters's fascinating Ethnic Options: Choosing Identities in America (Berkeley, 1990), or David Hollinger, Post-Ethnic America: Beyond Multiculturalism (New York, 1995) - and its clear suggestion on the other that assimilation is defined by a loss of authenticity.

J. M. MANCINI is college lecturer in the department of history at University College Cork—National University of Ireland, Cork. She has just completed a book manuscript entitled The Structure of an Artistic Revolution: The Critical Origins of American Modernism. She is currently working on a book to be entitled The Global Anthology: Hearing Country, Folk, and World Music Metadiscursively. "Discovering Viking America" is the first in a series of essays that will consider the historiography of migration from an international perspective. Her email is j.mancini@ucc.ie 


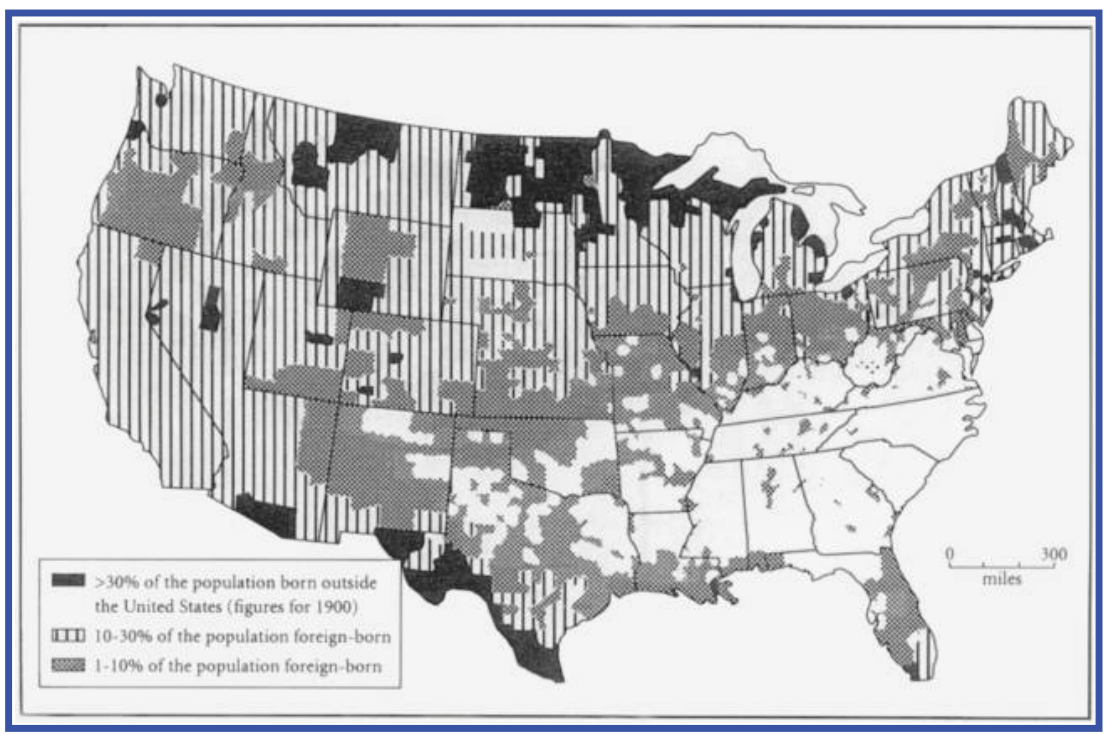

F I G U R E 1. The foreign-born population in 1900.

Knute Nelson, who as a Norwegian American was unable to reach Congress in the more settled district that included Minneapolis and Saint Paul, made his first successful entry into national politics in $\mathbf{1 8 8 2}$ only after the creation of a brand new congressional district in Minnesota's heavily immigrant Upper Country. ${ }^{3}$

Norwegians and other Scandinavian immigrants employed a similar strategy within higher education, first by founding a host of long-lived institutions of their own and then by making a place for themselves within the newly forming, less dug-in public universities of the west such as Minnesota, Iowa, Wyoming, and Anderson's own University of Wisconsin, which itself had created Anderson's position as a response to immigrant pressure. ${ }^{4}$ If figures like Nelson acted as political brokers between the im-

3. See Millard L. Gieske and Steven J. Keillor, Norwegian Yankee: Knute Nelson and the Failure of American Politics, 1860-1923 (Northfield, Minn., 1995), p. 99. As David Emmons has shown, this consolidation of the margins can also be seen in Irish America in the case of Butte, Montana, where the fact that the Irish were the "first" immigrants meant that they were able in large part to create, rather than merely to bend to, the social, cultural, political, and economic structures of the community. See David M. Emmons, The Butte Irish: Class and Ethnicity in an American Mining Town, 1875-1925 (Urbana, Ill., 1989).

4. Clearly there were differences between the constituent Scandinavian immigrant groups, and I do not wish to suggest that there were not. What is important in this context, however, is that authors from a number of different backgrounds-Norwegian, Swedish, Danish, Icelandic, and mixed-used the Vikings and used the more general strategies outlined here. 
migrant west and the established east, so too did Scandinavian American cultural politicians, and it was within this context that they began to pursue the Vikings. The literature of Viking discovery made a number of claims about the Scandinavian origins of the American past. First, it argued that the Vikings had been the true discoverers of America. Second, it argued that Scandinavians, as the progenitors of the American "race" and the creators of democracy itself, were America's ancestors in body and mind. And, finally, it argued not only that Scandinavians had arrived first but they had done it better, by suggesting that the Vikings had negotiated the most vexing aspect of New World discovery-contact with Native peoples and its genocidal implications-more successfully than their later rivals. In this way, Viking theorists inverted a discourse of discovery that usually limited the options of immigrants. For Scandinavians, discovery did not begin with Columbus and did not end in genocide. ${ }^{5}$

But if Scandinavian immigrants' claim to a special place within American culture was not based on assimilation to North American norms, it was not based on an assault on the native born, either. If discovery theorists were happy enough to blame Columbus for the bloodier aspects of the conquest of America, they were reluctant to condemn their Anglo-American hosts directly. Professor O. M. Norlie of Luther College, for instance, shuddered at the horror of the Columbian conquest but described the settling of the United States as harmonious and conflict-free. With a striking lack of irony, he wrote in his 1925 History of the Norwegian People that "the great migrations of the early centuries were nearly always accompanied by violence and bloodshed, by conquest and subjugation of the native population. The immigration to America has been peaceful."' Indeed, in both form and content, immigrant arguments for Viking discovery took the shape of a compromise with the elite. Discovery theorists were much more likely than immigrant novelists and poets to write in English, and they celebrated American institutions. Even the choice of Viking discovery as a theme for Scandinavian immigrant literature was governed by its simultaneous appeal to both immigrant and native-born constituencies; although Viking discovery became an ethnic literature, it was also a powerfully American theme

5. Of course, there were other factors that increased Scandinavians' "ethnic options." On the most obvious level, their ethnic and religious makeup make them less vulnerable to racism than other immigrants; as white Protestants, they managed to avoid the most abusive programs of assimilation other groups suffered, particularly before the First World War, and they were never in the racially liminal position occupied by Jewish or Irish immigrants. Nonetheless, the choices they made within this context were instrumental. For a fascinating look at how the limits placed on other immigrant groups could influence the outcome of such choices, see Michael Rogin, Blackface, White Noise: Jewish Immigrants in the Hollywood Melting Pot (Berkeley, 1996).

6. O. M. Norlie, History of the Norwegian People in America (Minneapolis, 1925), p. 73. 
by the end of the nineteenth century, appearing in numerous works by the native born. Within their discussions of Viking discovery, moreover, immigrant writers embraced contemporary elite discourses and cast their argument for acceptance in terms that clearly had been set by the native born. It was this strategy of compromise and appropriation that set Viking theorists apart and allowed them to make a case for their presence in America without embracing ethnic assimilation per se.

\section{Teutons, Brahmins, Skraellings, and Others}

The strategy of compromise and appropriation that underlay Viking discovery narratives began with the choice of this theme as a subject for Scandinavian immigrant writings. Although Viking discovery had a special meaning for Scandinavian immigrants, it also exerted a powerful pull on Americans engaged in the search for national myths from the mid-nineteenth century onward, and by choosing it immigrant authors accessed a sympathetic audience of native-stock readers. American fascination with the Viking discovery of the New World had begun in earnest in the middle of the nineteenth century, following in the footsteps of a Scandinavian rediscovery of the medieval past starting in the late sixteenth and seventeenth centuries. ${ }^{7}$ Increasing scholarly attention to the sagas in Scandinavia, followed by their translation into English by N. L. Beamish, Samuel Laing, and others, ${ }^{8}$ opened a new audience in both Britain and the United States for the masterworks of Old Norse literature, so that by the end of the nineteenth century readers of English could avail themselves of dozens of translations and treatments of the sagas. ${ }^{9}$ Whetted by the publication of Danish scholar

7. For a concise history of this revival as well as its transplantation to the United States, see Matti Enn Kaups, "Shifting Vinland-Tradition and Myth," Terrae Incognitae 2 (1970): 29-60. As Kaups notes, there was a long-standing Scandinavian and European debate on the Viking discovery of America well before such accounts became generally familiar to Americans, and as early as the late eighteenth century some Americans, most notably Benjamin Franklin, had a passing familiarity with the Vinland sagas. Still, it was not until the 1830 ond 1840 s that such accounts began to be widely spread.

8. See Antiquitates Americanae sive scriptores septentrionales rerum ante-Columbianarum in America, ed. Carl Christian Rafn (1837; Osnabrück, 1968), selections of which appear in The Discovery of America by the Northmen, in the Tenth Century, with Notices of the Early Settlements of the Irish in the Western Hemisphere, trans. North Ludlow Beamish (London, 1841); see also Snorre Sturlason, The Heimskringla, or the Sagas of the Norse Kings, trans. Samuel Laing, 4 vols. (London, 1839). Another popular translation was The Finding of Wineland the Good: The History of the Icelandic Discovery of America, trans. Arthur Middleton Reeves (London, 1895).

9. This included William Morris's handsomely produced Saga Library, published between 1891 and 1905. See The Saga Library, ed. Morris and Eiríkr Magnússon, 6 vols. (London, 1891-1905). The Vikings enjoyed a similar popularity at this time in Germany, leading to the translation of several accounts of Viking discovery into English. See, for example, Joseph Fischer, The Discoveries of the Norsemen in America, trans. Basil H. Soulsby (London, 1903), and J. G. Kohl, A Popular History of the Discovery of America, trans. Major R. R. Noel (London, 1865). 
Carl Christian Rafn's American Antiquities, ${ }^{10}$ an 1837 compendium of historical and literary documents proposing that the Vikings had discovered the shores of America five hundred years before Columbus, this general literary appetite for Norse literature quickly turned in the United States into a wide and sometimes contentious debate on the nature and scope of the Vikings' New World adventures. ${ }^{11}$ Thus the Vikings began to find a prominent position within general histories of the United States and of New England, ${ }^{12}$ literary works like Henry Wadsworth Longfellow's 1841 poem "The Skeleton in Armor," inspired by the discovery of a "Viking" grave in Massachusetts in the 1830s, and lectures such as Asahel Davis's admiring but vague dissertation on "the discovery of New England by the Northmen," which went through at least twenty editions by the end of the $1840{ }^{13}$

As the century wore on, Viking discovery became intertwined with lines of historical inquiry that linked race and politics in an attempt to explain American democracy as an outgrowth of a distant Anglo-Saxon, Teutonic, or Nordic past. As Robin Fleming has argued, in the last quarter of the nineteenth century medieval history enjoyed a lengthy heyday, as Henry Adams and others strove to bolster the authority of the Brahmin elite by forging a direct and unbroken link between the present, the intermediary past of the founding fathers, and a medieval past in which Teutonic tribes had planted the original seeds of contemporary democracy. ${ }^{14}$ With their

10. See Antiquitates Americanae sive scriptores septentrionales rerum ante-Columbianarum in America. Although the fact that this volume was initially published in Latin and Danish would have reduced its direct readership in the United States, soon after its publication extracts were translated and the volume was reviewed in English-language journals such as the Journal of the Royal Geographical Society of London, the North American Review, the Knickerbocker, the New York Review, and elsewhere, so that many more Americans would have been exposed to the ideas therein. For bibliographic information on Rafn's reception in English, see Halldór Hermannsson, "The Northmen in America (982-c. 1500): A Contribution to the Bibliography of the Subject," Islandica 2 (1909): 6-7, 65-68.

11. It also invited direct correspondence with Rafn himself on the part of American scholars eager to identify various archaeological finds that might point to Viking or other European presence. See, for example, Henry R. Schoolcraft, "Brief Notices of a Runic Inscription Found in North America," Memoires de la Société Royale des Antiquaires du Nord (1840-44):119-27.

12. See Charles W. Elliott, New England History from the Discovery of the Continent by the Northmen, A.D. 986, to the Period When the Colonies Declared their Independence, A.D. 1776, vol. 1 of The New England History (New York, 1857). See also the first volume of William Cullen Bryant and Sydney Howard Gay, A Popular History of the United States from the First Discovery of the Western Hemisphere by the Northmen, to the End of the First Century of the Union of the States, vol. 1 of The Popular History of the United States (New York, 1876).

13. A. Davis, A Lecture on the Antiquities of Central America, and on the Discovery of New England by the Northmen, Five Hundred Years before Columbus (New York, 1840), p. 21.

14. See Robin Fleming, "Picturesque History and the Medieval in Nineteenth-Century America," American Historical Review 100 (Oct. 1995): 1061-94. See also Reginald Horsman, Race and Manifest Destiny (Cambridge, Mass., 1981). 
supposed discovery of America nearly five hundred years before the more swarthy Columbus, the Vikings offered a special fascination to New Englanders. Notable citizens like Oliver Wendell Holmes, James Russell Lowell, and Edward Everett Hale clamored for a statue of Leif Erikson to commemorate Boston's other founding father (fig. 2), Viking-style trimmings adorned the fashionable homes of Newport, and Harvard University hoarded great numbers of "Viking" artefacts uncovered by M.I.T. professor Eben Norton Horsford, who devoted decades to proving through publications, tours, and large-scale endeavors in amateur archaeology that Leif Erikson not only had stumbled upon American shores, but had settled Cambridge itself (fig. 3 ). ${ }^{15}$

This craze for Viking discovery was joined to a surging interest in New England history and genealogy, exemplified by the work of Edmund Slafter. Slafter, who as an officer of Boston's Prince Society ${ }^{16}$ promoted the Viking discovery of America through his republication of Beamish's English translation of the sagas and who celebrated the eventual success of the Erikson statue movement, ${ }^{17}$ devoted most of his literary and historical attention to producing an intricate family history of New England..$^{18}$ In Slafter's writings, the historical triangle described by Fleming revealed itself in an emphasis on the primacy of the desire for freedom among the Vikings, the "AngloSaxon" colonials, and their present-day descendants. Thus, just as he characterized the Vikings' gradual westward movement as a reaction to the "despotic rule" of King Harald Haarfagr (rather than, say, a series of bloody and piratical quests for economic and political power), and the primary qualities of the colonial "patriarchs" as their "love of liberty," he also put in a strong word for the continued democratic tendencies of contemporary New Englanders. ${ }^{19}$ Indeed, Slafter went so far as to suggest that the historical

15. See Eben Norton Horsford, Sketch of the Norse Discovery of America (Boston, 1891), p. 25 and Leif's House in Vineland (Boston, 1893). For information on Horsford, see Stephen Williams, Fantastic Archaeology: The Wild Side of North American Prehistory (Philadelphia, 1991), pp. 206-10. On the "Viking Revival" in architecture, see Richard Guy Wilson, "Oscar Wilde, Colonialists, and Vikings: Newport and the Aesthetic Movement," Nineteenth Century 19 (Spring 1999): 4-11.

16. This organization, established in 1858 , was an affiliated society of the New-England Historic, Genealogical Society, named in honor of the eighteenth-century antiquarian Thomas Prince. Its purpose was "the publication of rare works" relating to the history of America and particularly New England, with the purpose of, as Slafter put it, "the perfecting of what we have begun as a library of New-England history.” Members included Charles Francis Adams, Charles Eliot Norton, and Francis Parkman (Edmund Slafter, Discourse Delivered before the New-England Historic, Genealogical Society [Boston, 1870], pp. 24, 31; see also Voyages of the Northmen to America, ed. Slafter [1877; New York, 1967], pp. 144-49).

17. See Slafter, The Discovery of America by the Northmen, 985-1015 (Concord, N.H., 1891).

18. See Slafter, Discourse Delivered before the New-England Historic, Genealogical Society, p. 12. This project began with the history of his own family in his Memorial of John Slafter, with a Genealogical Account of His Descendants (Boston, 1869).

19. Slafter, The Discovery of America by the Northmen, 985-1015, pp. 3-4. 


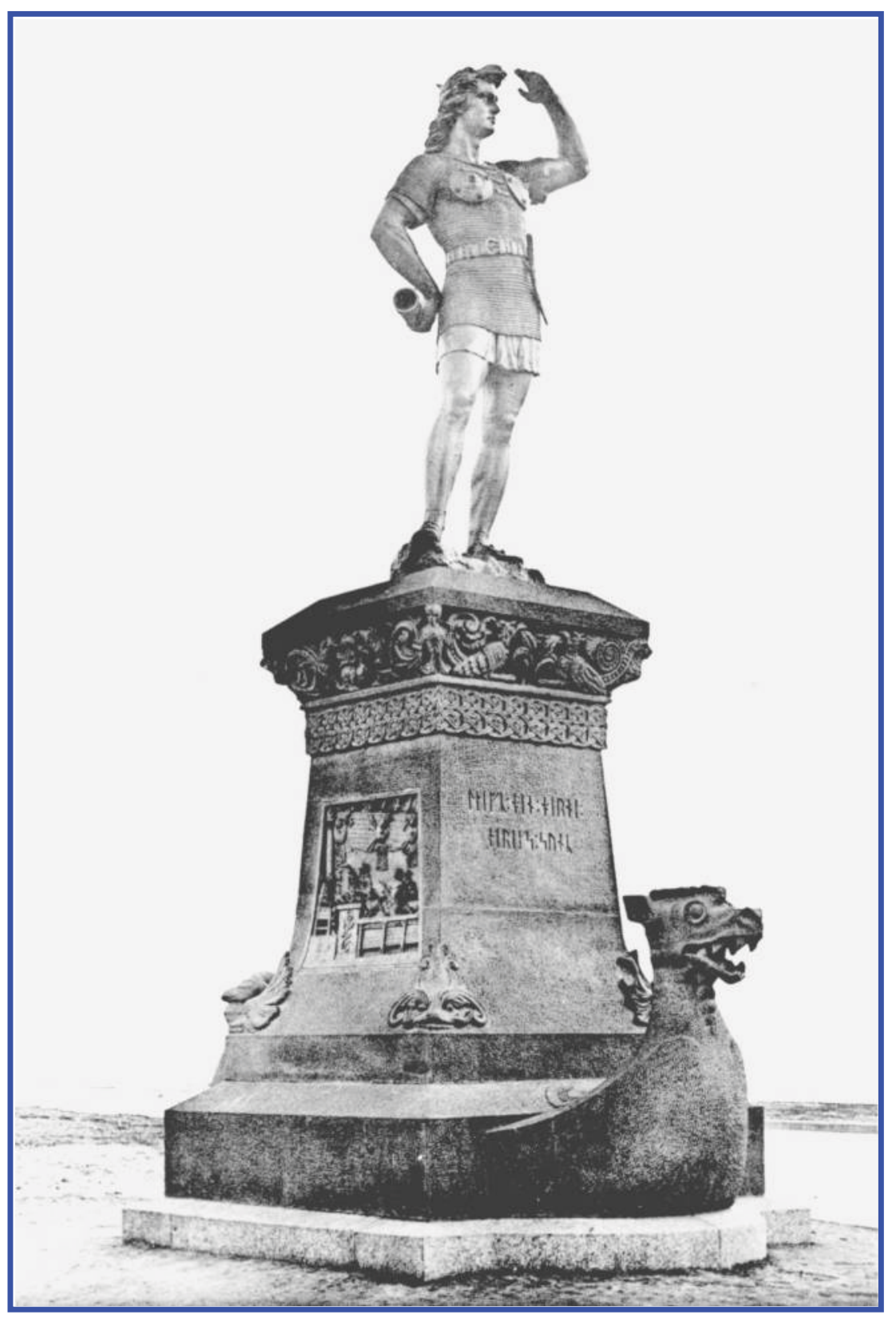

FIGURE 2. Boston's other founding father 


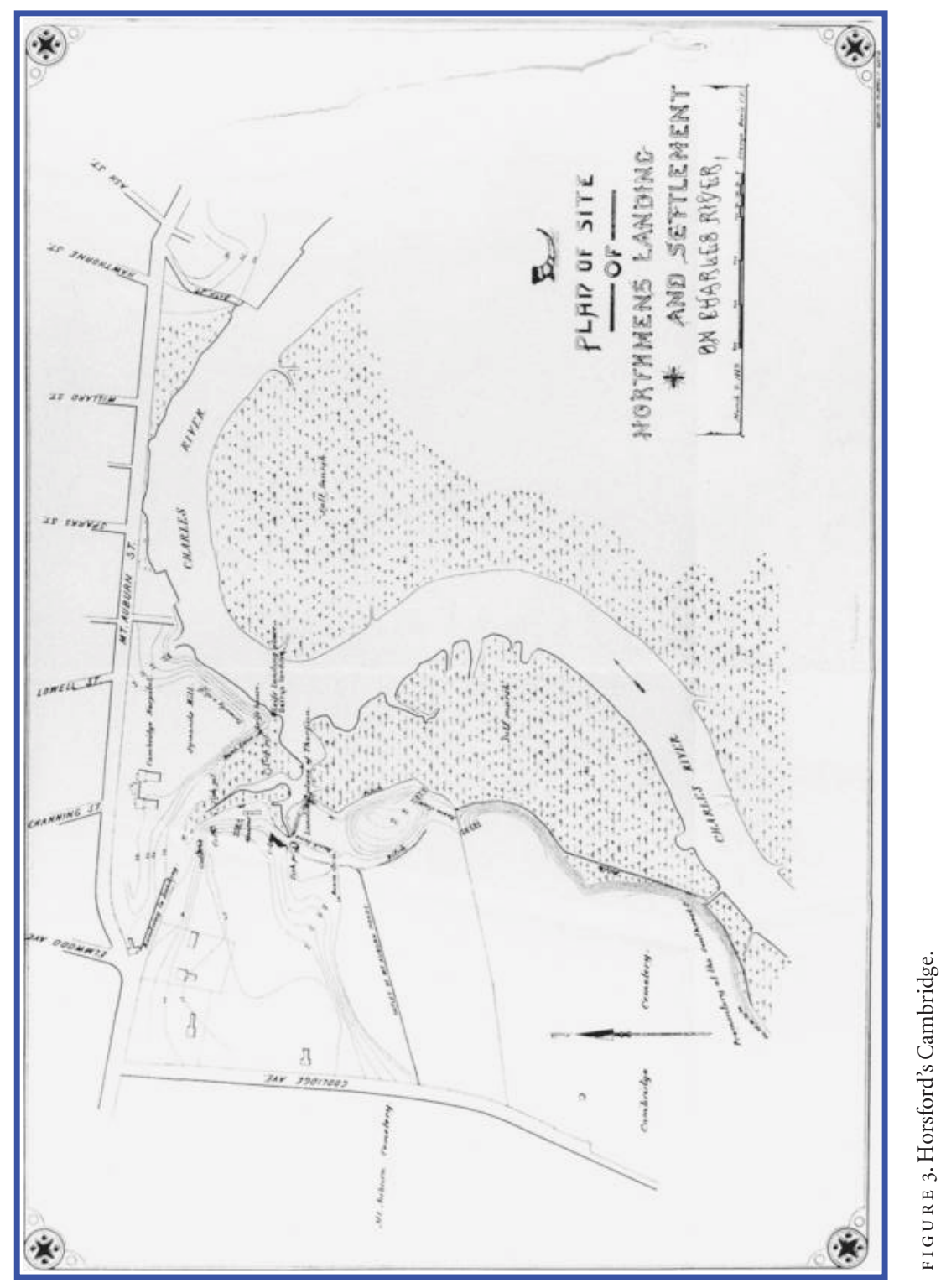


enterprise itself, as practiced in that region, was successful because its practitioners had sprung from "a people of unusual political and social equality, coming of the Anglo-Saxon stock, with an inheritance of many elements of character in which they always feel a just but not ostentatious pride." ${ }^{20}$ Slafter was so convinced of this connection between New Englanders and the Vikings, in fact, that he insisted that the Leif Erikson statue "should be placed in Boston, the metropolis of New England," despite harboring a deep skepticism towards most of the archaeological evidence in favor of the New England thesis. ${ }^{21}$ The prominent map of Cape Cod and Massachusetts Bay facing the title page of his Voyages of the Northmen to America, bearing the unequivocal title "A Map of Vinland, from accounts contained in Old Northern M.S.S.," made the same point in visual terms (fig. 4). Thus, while earlier writers such as Davis had represented the Norsemen as an appealing, though strange and distant people, towards the end of the century they were coming to resemble old friends or, more precisely, family.

The mainstreaming of Viking discovery in the last quarter of the nineteenth century served a similar purpose as that served by the larger trend towards racialized history. At a moment of increasing fear that the nation was committing race suicide, the thought of Viking ghosts roaming the streets of a city increasingly filled with Irish, Italian, and Jewish hordes must have been comforting to an Anglo-Saxon elite whose political power, at least, was decidedly on the wane. At the same time, claims to such virile ancestors as the Vikings also answered charges of effeminacy on the part of the literary elite, itself seen as part of the dangerous trend towards racial degeneration. Native-stock writers, however, were not the only ones to employ the Vikings for political purposes. Significantly, at the same time that native-stock writers were using Viking discovery to cope with the massive social and political transformations of the late nineteenth century, immigrants, who themselves comprised a major force behind these changes, also began to see that the Vikings could serve their interests.

The first volume by an American author of immigrant stock to turn to these themes was Rasmus B. Anderson's provocatively titled America Not Discovered by Columbus, first published in 1874 and reissued in several subsequent editions (fig. 5). Like native-stock writers, Anderson, the son of Norwegian immigrants and professor of Scandinavian languages at the University of Wisconsin, argued that a series of Norse adventurers, from 986 until the fourteenth century, had seen, touched, and settled America. ${ }^{22}$ With its uncritical catalogue of four decades of "evidence," including Viking place-

20. Slafter, Discourse Delivered before the New-England Historic, Genealogical Society, pp. 19, 11.

21. Slafter, The Discovery of America by the Northmen, 985-1015, p. 3.

22. During his long life, Anderson (1846-1936) was also United States minister to Denmark (1885-1889) and long-time editor of Amerika, a prominent Norwegian-American newspaper 


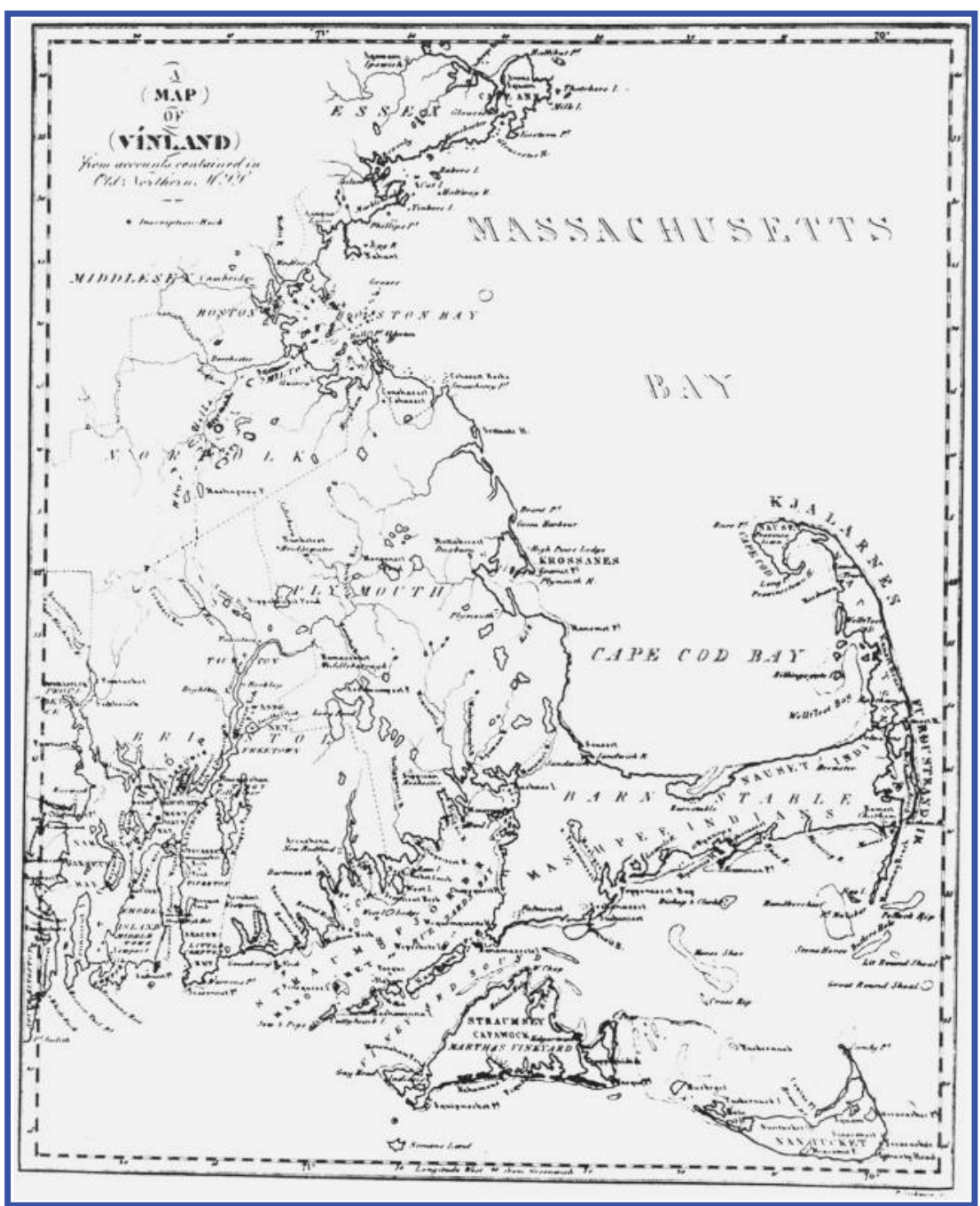

F I G U R E 4. "A Map of Vinland from accounts contained in Old Northern MSS," Voyages of the Northmen to America, frontispiece.

names on Cape Cod and Viking tablets in the Taunton River in addition to the standard "skeleton in armor," Anderson's volume was tinged with an air of fantasy, and some contemporaries were quick to accuse him of an

(1898-1922). For biographical information on Anderson, see Lloyd Hustvedt, Rasmus Bjørn Anderson: Pioneer Scholar (1966; New York, 1979); Paul Knaplund, "Rasmus B. Anderson, Pioneer and Crusader," Norwegian-American Studies and Records 18 (1954): 23-43; Einar Haugen,

"Wisconsin Pioneers in Scandinavian Studies: Anderson and Olson, 1875-1931," Wisconsin Magazine of History (Autumn 1950): 28-39; and C. W. Butterfield, Literary and Biographical Sketch of Prof. Rasmus B. Anderson (Madison, Wis., 1879). 


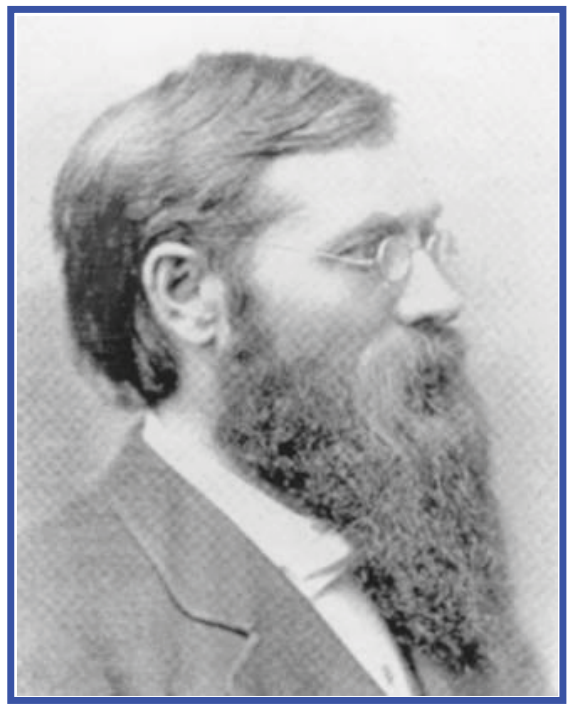

F I G U R E 5. Prof. R. B. Anderson, Madison, Wis.

excess of enthusiasm. ${ }^{23}$ Yet, although Anderson may have approached the limits of contemporary credulity with some of his claims, ${ }^{24}$ the work was well within the boundaries of the discovery discourse as practiced by the native-born cultural and social elite, an elite which surely was Anderson's intended readership.

That Anderson saw this elite as a significant audience for his work can be seen not only in the work itself but in his actions surrounding it. For one

23. Thomas Wentworth Higginson, for example, chided Anderson for his uncritical acceptance of two particular "finds": the Dighton Rock, which Anderson claimed to have runic inscriptions, and the Newport Tower, which Anderson insisted was a Norse, rather than a colonial, edifice. See Thomas Wentworth Higginson, letters to Anderson, 5 May 1877 and 10 June 1877, Anderson correspondence, State Historical Society of Wisconsin, Madison (SHSW), reel 1. See also Voyages of the Northmen, p. 137. For another skeptical view of the time, see Charles Rau, "Observations on the Dighton Rock Inscription," Magazine of American History 2, no. 1 (1878): 82-85.

24. Although skeptics such as Higginson questioned Anderson's credulity, he was hardly the last Viking theorist to see Norse ruins everywhere he looked. The Newport Tower, the Dighton Rock, and many other "Viking" sites and artefacts have had their promoters throughout the twentieth century and continue to inspire heated defences. See, for example, A. C. Clausen, Leif Erikson's Discovery of America (Spokane, Wash., 1938); Barthinius L. Wick, Did the Norsemen Erect the Newport Round Tower? (Cedar Rapids, Iowa, 1911); and Carl H. Strandberg and Glyn Nelson, "Possible Norse Settlement Traces on Cape Cod," unpublished ms., 196-?, Minnesota Historical Society (MHS). Even the usually sober Royal Ontario Museum produced a pamphlet in the 1960 s that giddily suggested that a trove of Viking swords and axes might actually have been left by Norse travellers to Northern Ontario. See A.D. Tushingham, The Beardmore Relics: Hoax or History? (Toronto, 1966). For a more skeptical analysis of these remains, see Johannes Brønsted, "Norsemen in North America before Columbus," Smithsonian Institution Annual Report for 1953 (Washington, D.C., 1954), pp. 367-405. 
thing, Anderson chose to write the volume in English, something he had not done with his previous books. ${ }^{25}$ Given the period's still-flourishing Norwegian-language press and the lack of English facility among many Norwegian immigrants, this decision suggests that Anderson did not view immigrants as his most important audience. ${ }^{26}$ Moreover, Anderson engaged in a crusade of publicity to bring the book to the attention of the native-born elite, sending copies and correspondence to numerous prominent historians, writers, and others (including President Rutherford B. Hayes), ${ }^{27}$ and even attempting to enlist Longfellow to write a letter of endorsement for it. ${ }^{28}$ Although the success of this campaign is hard to gauge, Anderson must have found it flattering to discover that a historical luminary such as George Bancroft would have "immediately secured it" upon its release and that the book gained a sufficiently positive response to gain him election to the Prince Society. ${ }^{29}$ Just in case these private measures were not enough to soften up these valued readers, Anderson added a lengthy preface in the second edition praising the worthy men of Boston who had contributed to the Erikson statue movement, ${ }^{30}$ just as he had dedicated his

25. This fact is noted in Butterfield, Literary and Biographical Sketch of Prof. Rasmus B. Anderson, p. 4

26. For information on the Norwegian immigrant press, see Arlow W. Andersen, The Immigrant Takes His Stand: The Norwegian-American Press and Public Affairs, 1847-1872 (Northfield, Minn., 1953), and Odd S. Lovoll, The Promise of America: A History of the NorwegianAmerican People, trans. Lovoll (Minneapolis, 1984).

27. See Rutherford B. Hayes. letter to Anderson, 15 Oct. 1878, Anderson correspondence, SHSW, reel 1.

28. Longfellow refused on the grounds that he had never written a letter "of that nature" but assuaged Anderson's fears by writing that the book was "interesting and valuable," that it would "make its own way in the world," and that Anderson's work would give "name and fame to you and to your University" (Henry Wadsworth Longfellow, letter to Anderson, 11 Aug. 1875, Anderson correspondence, SHSW, reel 1). Anderson continued to send later works and information to Longfellow, who received his correspondence enthusiastically. See Longfellow, letters to Anderson, 1 Nov. 1876, 28 Nov. 1876, and 15 Dec. 1879; see also Edith Longfellow, letter to Anderson, 19 May 1875, Anderson correspondence, SHSW, reel 1.

29. George Bancroft, letter to Anderson, 26 Apr. 1877, Anderson correspondence, SHSW, reel 1. Even the doubter Higginson wrote, "the book as a whole seems to me of value as popularizing certain facts and traditions with which people ought to be familiar, and I thank you for your courtesy in sending it" (Higginson, letter to Anderson, 10 June 1877, Anderson correspondence, SHSW, reel 1; see also Charles W. Tuttle, letter to Anderson, 9 Mar. 1878, Anderson correspondence, SHSW, reel 1). Anderson also corresponded on Northern matters with Bayard Taylor, a self-described "admirer of the Scandinavian race and poetry" (Bayard Taylor, letter to Anderson, 12 Dec. 1874, Anderson correspondence, SHSW, box 19), successfully proposed a book swap with University of Pennsylvania anthropologist Daniel G. Brinton (see Daniel G. Brinton, letter to Anderson, 13 Dec. 1882, Anderson correspondence, SHSW, box 26), and had a lengthy correspondence with E. N. Horsford and his daughter Cornelia, who carried on the Viking project after her father's death.

30. An idea for which Butterfield somewhat dubiously credits Anderson in the first place. See Butterfield, Literary and Biographical Sketch of Prof. Rasmus B. Anderson, p. 5. 
earlier book on northern mythology to Longfellow. ${ }^{31}$ Thus, unlike many purveyors of immigrant literature, Anderson did not primarily reach inward with his work in order to bolster an insecure ethnic community through accounts of hardship and survival and did not propose assimilation as the path by which that community would gain a solid foundation within American society as a whole. ${ }^{32}$ In Anderson's hands, immigrant literature was a project that reached outward to those who set the boundaries of immigrant participation in American life, while working to stretch those boundaries by redefining the immigrant community in terms that flattered, rather than challenged, the native-born elite..$^{33}$

This strategy can be seen most readily in the text itself. Anderson's designation of New England as the site of Viking landing, for instance, can hardly have been accidental. ${ }^{34}$ Indeed, it seems that Anderson's volume was a plea to the same Brahmin audience that in its softer moments produced sentimentalized accounts of Viking discovery and the democratic inheritance of the Teutonic race but that in everyday practice was not always welcoming to newcomers from the fjords and farms of Norway. ${ }^{35}$ Thus, just as

31. A dedication to which Longfellow seems to have responded favorably. The title of the volume was Norse Mythology: The Religion of Our Forefathers Containing All the Myths of the Eddas, Systematized and Interpolated (Chicago, 1875). See Longfellow, letters to Anderson, 10 Mar. 1873 and 11 Aug. 1875, Anderson correspondence, SHSW, reel 1.

32. Sometimes, Anderson's pleas to the native born to accept the continuity of immigrant ways took a more direct form. In his First Norwegian Settlements in America within the Present Century, for instance, Anderson directly addressed the native-born reader with the admonition that "you should not blame the foreigners for clinging to their language and traditions. By doing so they bridge the Atlantic ocean and bring to this country the fruits of all the progress made from year to year in Europe," without which American society would be immeasurably poorer (Anderson, The First Norwegian Settlements in America within the Present Century [1898; Madison, Wis., 1899], p. 167). For a thorough overview of Scandinavian immigrant literature in its other guises, see Dorothy Burton Skårdal, The Divided Heart: Scandinavian Immigrant Experience through Literary Sources (Lincoln, Nebr., 1974).

33. Due to the success of his Viking writings and his "authentic" position as a scholar of Scandinavian literature, Anderson also had something more concrete to offer to certain nativestock enthusiasts of the Vikings: positive reviews of their books. Rabid anti-Columbian Viking theorist Marie Brown Shipley, for example, virtually begged Anderson to review her translations of Swedish literature, "and in the 'Nation,' by preference," so that she could successfully selfpublish them and avoid the "treachery" of greedy publishing houses (Marie A. Brown, letters to Anderson, 29 Nov. 1878, 3 Feb. 1879, and 15 Mar. 1879, Anderson correspondence, SHSW, box 22).

34. And, it might be added, contrasts with the tendency of twentieth-century Viking theorists of immigrant descent to emphasize the hypothesis that, wherever they may have landed initially, the Vikings somehow managed to wind up in Minnesota or other parts of the Middle West with a deeper connection to the immigrant community itself.

35. As Barbara Miller Solomon writes, the relative distance of most Scandinavians from the teeming masses of immigrants in the eastern cities did not always prevent them from being seen as objectionable. While Charles Francis Adams, Henry Cabot Lodge, and other late nineteenthcentury defenders of Teutonic superiority frequently saw Scandinavians and Germans, particularly in the rural west, as the last hope for racially healthy immigration, other observers in the late nineteenth century blamed all non-English " old" " immigrants, including Scandinavians, for "the degradation of American civilization," which the arrival of even stranger new groups in the last decades of the century had only furthered (Barbara Miller Solomon, Ancestors and 
Adams's work was intended to draw a direct link between the Teutonic democrats of the medieval past and the Brahmins of the nineteenth century, Anderson's tract was meant to remind people like Adams that those Norwegians who had just stepped off the boat were the direct descendants of the original settlers, who

were the descendants of a branch of the Teutonic race that, in early times, emigrated from Asia and traveled westward and northward, finally settling down in what is now the west central part of the kingdom of Norway .... They were a free people. Their rulers were elected by the people in convention assembled, and all public matters of importance were decided in the assemblies, or open parliaments of the people. $[A, \text { p. 49 }]^{36}$

With its emphasis on the freedom-loving racial characteristics of the Norwegians, Anderson's account seems designed to suggest to Americans that their own racialist ideology implied that race, rather than ethnicity or national origin, should be the primary category for judging immigrants and that Scandinavians' racial heritage would make them good Americans without abusive programs of assimilation. After all, as the quotation at the beginning of this essay shows, Americans themselves owed their best qualities, at least in part, to the Norsemen. ${ }^{37}$ Lest anyone should mistake the persistence of the Norse "spirit" for a vague or coincidental sympathy of mind, Anderson made sure to mention that both Englishmen and Americans owed not only their habits but their actual lines of descent to the Norman conquest and earlier Norse incursions, stopping just short of claiming that George Washington himself was descended from the Vikings. ${ }^{38}$

Immigrants: A Changing New England Tradition [Cambridge, Mass., 1956], p. 159; see also pp. 31, 160). For a comprehensive look at attitudes towards immigrants in the Midwest in the nineteenth century, see Jon Gjerde, The Minds of the West: Ethnocultural Evolution in the Rural Middle West, 1830-1917 (Chapel Hill, 1997), esp. chaps. 1-2.

36. Anderson was not the only ethnic writer to situate the Viking discovery of America within the context of an inevitable westward Aryan progression. This cause was also taken up by the Danish/Norwegian-American Harold W. Foght, who wrote that

the Aryan migration, although it commenced thousands of years ago while the history of man was young, has not yet come to an end ... the overflow is being dispersed over the whole earth, peopling America and Australia, setting up there and elsewhere, a new and powerful dominion over the aborigines. Wherever they go the Aryans carry with them their enlightenment. [Harold W. Foght, The Norse Discovery of America, with Some Reference to Its True Significance (Blair, Nebr., 1901)]

For a comprehensive discussion of the idea of the westward progression of the Aryan people and their origins, see Horsman, Race and Manifest Destiny.

37. Elsewhere, Anderson also made the more conventional claim that Norwegians were patriotic, industrious, and quick to learn English. See Anderson, First Norwegian Settlements within the Present Century, p. 167.

38. Certain later Norwegian-American writers such as Olaf Morgan Norlie, who sweepingly attributed Norse origin to the "Pilgrim Fathers" and their descendants, did not show this restraint (Norlie, History of the Norwegian People in America, p. 24). 
Anderson's strategy of compromise without assimilation may have placed him in the somewhat undignified role of a salesman, forced to flatter the racial, social, and political vanities of his most desirable customers, but it would be a mistake to think that he expected nothing in return. ${ }^{39}$ In fact, Anderson made significant demands in this exchange, asking specifically that Americans not only accept Scandinavians as their brethren but rewrite their own history. It was not enough for a few books here and there to toss in a word or two about the Vikings; Anderson demanded that the prototypical agent of assimilation and Americanization, the public school, should teach American children that the Norse were Americans' common ancestors. ${ }^{40}$ Charging that Leif Erikson, his brother Thorvald, and others like them should "become household words in every house and hamlet in these United States," he exhorted Americans to "let every child learn the stories about the Norse discoverers of Vinland the Good" (A, p. 34). Although there is no evidence to suggest that the historical profession dropped everything to follow his command, it should be noted that many of the native-stock Viking books, including Slafter's, were published after Anderson's. Moreover, the American Historical Association invited Anderson's son-in-law, Julius Olson, to coedit the first volume of J. Franklin Jameson's Original Narratives of Early American History series, The Northmen, Columbus, and Cabot, 985-1503, published in 1906. ${ }^{41}$

Anderson's text also employed more specific strategies for insinuating the Norsemen into the heart of American national history. In particular,

39. One other risk of this strategy was that it would lead to a cartoonish typecasting of Norwegians and their culture. Indeed, although Anderson's Viking campaign was successful in creating a positive image of Scandinavians, it did nothing to further his simultaneous goal of spreading the good word about contemporary Scandinavian culture. As it turned out, editors such as S. S. McClure and J. B. Gilder of the Critic wanted "stirring viking stories of adventure," but not Ibsen (S. S. McClure, letter to Anderson, 17 Oct. 1890, Anderson correspondence, SHSW, box 32; see also J. B. Gilder, letters to Anderson, 14 Apr. 1882 and 18 Dec. 1882, Anderson correspondence, SHSW, boxes 25 and 26)

40. It should be pointed out that at least one critic of Anderson and his fellow Viking theorists was unpersuaded by this line of argument not just because the critic disputed Anderson's evidence for Norse discovery but because he scorned the Norse character itself. Rather than a culture of "freedom and enlightenment," J. P. MacLean insisted that the Vikings were "lawless in a bad sense," their natures "more savage than that of any North American Indian at the time of the discovery," and ridiculed Anderson and others like him for attributing all progress and enlightenment to the "fable" of "our Saxon inheritance." As MacLean himself indicated, however, his view was not a common one (J. P. MacLean, A Critical Examination of the Evidences Adduced to Establish the Theory of the Norse Discovery of America [Chicago, 1892], pp. 52, 53, 54).

41. Olson himself was preoccupied with this issue and believed that the Viking discovery of America was the best tool to put Norwegians "in the front part of American history books" and to thereby erase the backwoods image of Norwegians among "Plymouth-Rock-Americans" (Julius Olson, "The Vinland Voyages," speech delivered at Leif Erikson Day Festival, Chicago, 1923, unpublished ms., Olson Papers, Norwegian American Historical Association, Northfield, Minn. [NAHA]). 
Anderson appealed to historical connections among race, geography, and religion, constructing the Vikings' forays into New England as a preparation for the Puritan arrival. In the first instance, Anderson argued that the Vikings had taken possession of the landscape by giving it place-names that survived to the modern era, presumably passed down through the Native population. ${ }^{42}$ Quoting at length from a tract sent to him by "Joseph Story Fay, Esq., of Wood's Holl, Massachusetts," Anderson promoted the idea that this town's name had been "given" to the Indians by the Vikings, for whom the word holl signified hill, and that it had stuck because of the Indians' own linguistic weakness ( $A$, p. 24 ; see p. 28 ). ${ }^{43}$ Anderson also suggested that the Vikings had prepared New England for the Puritans by bringing Christianity to its shores. Despite a nod to the "flower of Teutonic heathendom" (and despite the fact that Christianity had at best only partially penetrated Viking culture by the time of the Vinland voyages), Anderson repeatedly emphasized the Christianity of the Norsemen. More than that, Anderson implied that the Vikings had been the right kind of Christians to bring religion to America by distinguishing them from Columbus, who "talked of himself as chosen by Heaven to make this discovery" but was "subservient to the dominion of inquisition." What Anderson avoided saying, of course, was that the Vikings were as Catholic as Columbus $(A, \mathrm{pp} .57,91),{ }^{44}$ even if their

42. In this, Anderson foreshadowed similar arguments attributing Norse ancestry to various Indian languages and linking English place-names to the Norse discovery. See, for example, Wilfred Harold Munro, Tales of an Old Sea Port (Princeton, N.J., 1917), which claimed that Rhode Island's Mount Hope was originally "Hóp," from the Icelandic for "bay," a claim echoed in Matthias Thórdarson, The Vinland Voyages, commissioned for an American audience by the American Geographical Society (Matthias Thórdarson, The Vinland Voyages, trans. Thorstina Jackson Walters [New York, 1930], p. 42).

43. Anderson was not the last to argue for a Norse origin to Native languages. In the 1940s and 1950s, Norwegian-American Reider Thorbjorn Sherwin compiled an eight-volume lexicography outlining the "Old Norse origin of the Algonquin language." See Reider Thorbjorn Sherwin, The Viking and the Red Man: The Old Norse Origin of the Algonquin Language, 8 vols. (New York, 1940-56).

44. That Anderson had tapped into a powerful vein of anti-Catholicism in his support of the Vikings can be seen in the comments made by Marie Brown (later Shipley) before the U.S. Senate during an 1888 hearing to decide whether to recognize officially the discovery of America by Leif Erikson:

The vital and all-absorbing question now is, whether this American Republic, founded on surely secular principles, wishes to pay posthumous honors, on a scale of unprecedented magnificence, and at the bidding of the pope, and the countries under his dominion ... to the Roman Catholic missionary and devotee, Christopher Columbus, who was sent out by the Church of Rome to convert the natives of a land whose locality he knew, having ascertained it definitely in Iceland before he started forth on his voyage to the western continent. [To do so] would be to publicly sanction the claims of the Church of Rome to this land, and virtually to invite the pope to come and take possession of it. [Brown, "Leif Erikson," speech delivered 23 Mar. 1888, MHS] 
descendants had turned away from the Church of Rome to a religion seemingly more appropriate for aspiring Americans. ${ }^{45}$

Although the mere presence of Christian Norsemen in Anderson's narrative would have served to connect the Vikings and the Puritans, Anderson strengthened this association by representing Viking New England as a place steeped in sanctifying Christian blood. The death of Leif Erikson's brother Thorvald, he suggested, had been one of the most significant episodes in the Vikings' New World history because it had consecrated America as a Christian land and, by implication, set the stage for the arrival of later Christians. Thorvald, he exclaimed, "was buried in Vinland, and two crosses were erected on his grave, - one at his head and one at his feet. Hallowed ground, this, beneath whose sod rests the dust of the first Christian and the first European who died in America!" (A, p. 75). In describing the Viking Christianization of New England in these terms, Anderson provided an additional incentive for native-stock Americans to accept the Vikings as the "discoverers" of New England; his account of this incident sidestepped the increasingly sensitive issue of anti-Native violence on the part of European colonists. ${ }^{46}$ In direct contrast to known accounts of the post-Columbian

See also Shipley, The Norse Colonization in America by the Light of the Vatican Finds (Lucerne, 1898). While this suspicion of Rome persisted until well after the turn of the century in Viking narratives, by the 1930s authors had come to embrace a more inclusive view of discovery and its symbols. The vice president of the Minnesota Leif Erikson Monument Association, for instance, insisted in 1934 that "there is ample room for honoring both of these men" (E. Klaveness, "Leif Erikson and Christopher Columbus," radio address, St. Paul, 1934, MHS); see also Ola Johann Saervold, The Discovery of America (Minneapolis, 1931), who suggests that Columbus learned about America from the Icelanders but that this was a sign of his "earnestness and diligence" (p. 14). For a twentieth-century discussion of the Vikings that preceded this change of heart, see Olson, "The Teutonic Spirit: An Address Delivered on the Occasion of the Unveiling of a Statue to Rollo of Normandy, at Fargo, N. Dakota, July 12th, 1912” (Minneapolis, 1912).

45. While Anderson's convenient neglect of the Catholicism of the Vikings seems calculated to provide a means of distinguishing Protestant Norwegians from other groups of immigrants, the fact that they were followers of the Church of Rome was picked up by Catholic writers and used to demonstrate the fitness of Catholics as Americans. The renowned Catholic historian John Gilmary Shea's 1855 History of the Catholic Missions, for instance, began with a chapter on the "Norwegian Missions in New England." In it, Shea explicitly attempted to restore Catholics to their proper place in American history by arguing that the Vikings were Catholics and that the Catholic Church had as a result been the first European institution not only in the New World generally, but in the United States itself. See John Gilmary Shea, History of the Catholic Missions among the Indian Tribes of the United States, 1529-1854 (1855; New York, 1969). Other Catholic appropriations of the Vikings include Vincent A. Yzermans, "Our Lady of the Runestones," Marian Era 5 (1964): 73-73, 106-7; Sister Mary Jean Dorcy, “Ave Maria, Save Us from Evil,” Our Lady's Digest 38 (Fall 1983):37-42; and Raphael M. Huber, "Pre-Columbian Devotion to Mary in America: The Testimony of the Kensington Stone," American Ecclesiastical Review 118 (July 1947): 7-21.

46. The desire to clean up the violent reputation of the Vikings also penetrated the accounts of later Norwegian-American authors such as Knut Gjerset, whose Norwegian Sailors in American Waters: A Study in the History of Maritime Activity on the Eastern Seaboard (Northfield, Minn., 1933) fulminated against "the fallacious notion ... that they were merely adventurers and lawless buccaneers" (p. 8); a similar tendency can be seen in the official statement of purpose of the 
Christianization of the New World, in Anderson's tract the event that enabled the sacralization of the American landscape was not the brutal conversion and death of American Indians, but the European Thorvald's murder at the hands of marauding Natives, the Skraellings of the sagas. Writing that "the Norseman had no fire-arms, and their higher culture could not defend them against the swarms of savages that attacked them," Anderson suggested that New World Christianity had been born not in the brutal conversion and decimation of Aboriginal peoples but in blood spilled by European Vikings upon the shores of Massachusetts $(A, \mathrm{p} .91)$. In thus offering victimized Vikings as the true colonizers of New England, Anderson offered a salve to Americans' (and particularly New Englanders') increasingly guilty conscience about "the future of the Indian," whose degradation and disappearance were becoming causes célèbres (due to the work of Lewis Henry Morgan and other practitioners of the emerging field of anthropology), ${ }^{47}$ and whose fate was frequently pondered by defenders of the Viking theory of New World discovery. ${ }^{48}$

This imaginative refiguring of discovery provided the basis for an interesting bargain between Norwegians and the native born, for it suggested

Minnesota Leif Erikson Monument Association, which complained that "the general understanding of Leif Erikson seems to be that he was an adventurer, a sea-rover of some kind, an uncouth Viking. This is a complete misunderstanding of the man" (Minnesota Leif Erikson Monument Association pamphlet, 1931, p. 2, MHS; see also Louis H. Roddis, The Norsemen in the New World [Minneapolis, 1923], pp. 22-23).

47. Concern over this issue can be seen in government and pedagogical publications of the time, as well; for example, the Department of the Interior's representative at the Philadelphia Exhibition of 1876, John Eaton, published a dire volume entitled Are the Indians Dying Out? (Washington, 1877), and the introduction to a mid-nineteenth-century edition of Robertson's Discovery of America intended for use in the schools included the warning that perceptive readers had found Robertson's descriptions of Cortez and other Spanish conquerors too forgiving; see John Frost, "The Life of Dr. Robertson," in William Robertson, The History of the Discovery and Settlement of America (1777; New York, 1858), p. xxiii.

48. William J. Miller's Notes Concerning the Wampanoag Tribe of Indians, with Some Account of a Rock Picture on the Shor of Mount Hope Bay, in Bristol, R.I. (Providence, R.I., 1880), for instance, combined a regretful and nostalgic look back at the noble life and shocking death of King Philip with a somewhat extraneous account of the discovery of America by the "hardy Norse" (p. 5). In an interesting twist, Miller located Leif Erikson's settlement at the same spot as Philip's death, the aforementioned Mount Hope/“Hóp.” Similarly, Charles G. Leland's disquisition on the Norse origin of Algonquin religion and myth mournfully asked,

when the last Indian shall be in his grave, scholars will wonder at the indifference of the "learned" men of these times to such treasures as they have allowed to perish. What the world wants is not people to write about what others have gathered as to the Indians, but men to collect directly from them.

(Charles G. Leland, "The Edda among the Algonquin Indians," Atlantic Monthly 54 [Aug. 1884]: 234). This association of Norse discovery and Indian disappearance can also be found in Shea's History of the Catholic Missions, which explicitly argued that the Catholic colonization of the New World had been far less devastating than its Protestant counterpart, and implied that a successful Viking colonization might have prevented the later decimation of Northern tribes. 
that by accepting the Norsemen as ancestors and brethren, Americans could rid themselves of one of the most troubling aspects of their collective past. It also served the needs of Scandinavian newcomers to the West, who themselves grappled not only with real Natives but with the sticky issue of their own complicity in the brutal conquest of Indian lands. As the uneasy encounter with a Native grave by the pioneer Hansa family in Ole Edvard Rølvaag's Giants in the Earth indicates, immigrant writers would become preoccupied over the ensuing decades with the sense that there was something ominous about staking claims to land which had been declared by the authorities to be empty but which, upon closer inspection, contained living Indians as well as their history ${ }^{49}$ While Rølvaag's conclusion, made in hindsight in the 1920s, seems to have been that complicity in manifest destiny and a too-uncritical attitude towards the ideals of the native born had brought Norwegians only insanity and death, Anderson's tract of the $1870 \mathrm{~s}$ suggested that Norwegian-American history itself held the key to the problem of cultural contact. A compromise with America was the only route to immigrant success.

\section{Westward the Course}

At the end of the nineteenth century, then, it appeared as though the Viking discovery of America was poised to play an important role within American literary and historical consciousness. And, yet, it has not. While American popular culture is glutted with the cast-off symbols of Scandinavian-American nation-building-the horned hats that the Vikings famously never wore- as historical figures the Vikings barely appear on the American radar. Indeed, although Norse discovery was the subject of a recent Smithsonian exhibition, which was preceded by rousing press releases of Hillary Clinton praising "the power of the human spirit," the exhibition did little either to promote a strong narrative of Viking discovery or to grapple with the historical and cultural meaning of that discovery. ${ }^{50}$ Aside from a few cases filled with archaeological copies, a bit of lonely north-

49. See Ole Edvard Rølvaag, Giants in the Earth: A Saga of the Prairie, trans. Rølvaag and Lincoln Colcord (New York, 1927). Not all immigrant writers were as ambivalent about western land taking as Rølvaag. As April Schultz points out, the authors of the 1925 pageant celebrating the centennial of Norwegian settlement in North America represented Norwegian pioneers as peaceful civilizers of the wilderness, who shared peace pipes and plans for cultivation with Indians who had already agreed to leave without a struggle. See April Schultz, Ethnicity on Parade: Inventing the Norwegian American through Celebration (Amherst, Mass., 1994), pp. 5-6, 120-21. 50. Hillary Rodham Clinton, "Remarks," National Museum of Natural History, Baird Auditorium, NMNH, Washington, D.C., 8 Apr. 1999, http://www.mnh.si.edu/exhibits/vikings/ firstlady.html. That is not to say that the show did not attract a fair amount of public interest, including cover stories in Time and National Geographic. See Michael D. Lemonich and Andrea Dorfman, "The Truth about the Vikings," Time, 8 May 2000, pp. 68-78, and Priit J. Visilind, "In Search of Vikings," National Geographic 197 (May 2000): 2-27. 
ern video footage, and some panels vaguely praising Native culture, the most the exhibition seemed to offer was the bland suggestion that the Vikings were farmers and traders, farmers and traders, farmers and traders. Even the saga storytelling hut cut off its narrative before the killings began and contact really happened. The result was a history that, literally without blood, could not either present a coherent vision of cultural contact or further our understanding of its historical implications.

There are several reasons for this. The first has to do with the climate surrounding public history that has developed during the past decade or so. The Enola Gay controversy and the preceding furore over the West as America exhibit most certainly have undermined the potential for all but the blandest kinds of public history in the United States. ${ }^{51}$ With its Barneyized content and its casual corporate references, Vikings: The North Atlantic Saga seemed better designed to sell Volvos, Husqvarma chain saws, and Leif Erikson puppets than to delve into the fraught question of cultural contact. Yet, the degradation of public history after Enola Gay can only explain so much. After all, the exhibit reflected more than it created, and what it reflected is the larger absence of the Vikings from academia, the schools, or, with a few exceptions, American public history.

So, then, how to explain this disappearance of the Vikings from American historical consciousness? It certainly cannot be explained by a falling away of interest on the part of Scandinavian-American authors after Anderson. The twentieth century has seen the growth of a vast literature of this kind, exemplified by the most widely circulated of all the Viking discovery narratives, Hjalmar R. Holand's Norse Discoveries and Explorations in America, $982-1362,{ }^{52}$ still in print after sixty years and superficially very similar to Anderson's work. Like Anderson's narrative, Holand's work proposed an archaeological argument in favor of Viking discovery, this time in the form of the Kensington Stone, a 202-pound runestone purportedly uncovered by a Minnesota farmer in $1898 .{ }^{53}$ And, like America Not Discovered

51. On the Enola Gay controversy and the limits of public history in the United States, see David Thelen et al., "History after the 'Enola Gay' Controversy: An Introduction," Journal of American History 82 (Dec. 1995): 1029-115.

52. See Hjalmar R. Holand, Norse Discoveries and Explorations in America, 982-1362: Leif Erikson to the Kensington Stone (New York, 1968). This volume was originally published in 1940 under the title Westward from Vinland: An Account of Norse Discoveries and Explorations in America, 982-1362 and as a pamphlet called "The Kensington Stone" in 1932.

53. Holand was neither the first nor the last to promote the authenticity of the Kensington Stone. Over the past hundred years it has had many adherents and detractors, and it still inspires heated and sometimes unfriendly debate. Indeed, it seems that nearly every citizen of the Midwest has weighed in on the Kensington Stone at some point, including Frederick Jackson Turner. This is particularly true in Minnesota, where it has become a significant part of the local popular culture and where narrative legitimizations of the stone are abetted by a shrinelike museum and 
by Columbus, Holand's narrative also argued strenuously both for the Vikings' Christianity and for their victimization. To Holand, the Kensington Stone embodied the Vikings' Christian martyrdom, representing the dying lament of a party of Vikings who, having "been suddenly overwhelmed, killed and scalped by a party of Indians," had managed to carve a runic account of their demise and appeal to the Virgin before disappearing into the mists of time..$^{54}$

For all of these similarities, however, Holand's text differed from Anderson's in two key respects. Ironically, these differences account both for the popularity of the book and for its failure as a work of immigrant political claim staking. The first difference was its originality. Unlike Anderson, whose work was in the main a glossed translation of the Vinland sagas, Holand created his own narrative, out of local sources, in order to forge a new narrative of Viking discovery. This decision to stray from the sagas, which even in translation could be cumbersome and inscrutable, enabled Holand to perform the narrative chases and leaps that make the book such a good read: the visceral scenes of bloody Vikings, imagined by Holand as victims not of extinct New England tribes but of still-feared and admired Sioux; the titillating suggestion that the Vikings' survivors had intermarried with the Mandans, producing a fair race of "White Indians," still extant in the days of Lewis and Clark; and the absurd but locally pleasing claim that Vikings had penetrated deep into the continent, naturally choosing Minnesota as their western home.

monument erected near the site of its "discovery." As a result, nearly all discussions of the stone have been cast in terms of truth versus falsehood, and with few exceptions little has been said about its cultural significance independent of its status as an authentic relic from pre-Columbian times. What is usually left unsaid in these discussions is the fact that the very persistence of the stone in the face of its highly dubious origin is what makes it interesting. A brief selection of these treatises includes Theodore C. Blegen, The Kensington Rune Stone: New Light on an Old Riddle (St. Paul, Minn., 1968); George T. Flom, The Kensington Rune-Stone: A Modern Inscription from Douglas County, Minnesota (Springfield, Ill., 1910); S. N. Hagen, “The Kensington Runic Inscription," Speculum 25 (July 1950): 321-56; Carl Christian Jensen, "Rune Stone Controversy," unpublished ms., July 1969, MHS; History of Douglas and Grant Counties, Minnesota: Their People, Industries, and Institutions, ed. Constant Larson, 2 vols. (Indianapolis, 1916), 1:72-122; Vincent H. Malmstrom, "In Quest of Vikings: A Personal Inquiry into the Mystery of the Kensington Stone," Middlebury College Newsletter (Spring 1970): 19-26; Erik Moltke, "The Kensington Stone," Antiquity 25-26 (June 1951): 87-93; Jeffrey R. Redmond, "Viking" Hoaxes in North America (New York, 1979); Erik Wahlgren, The Kensington Stone: A Mystery Solved (Madison, Wis., 1958) and “The Case of the Kensington Rune Stone," American Heritage 10 (Apr. 1959):34-35, 101-5; The Museum Committee of the Minnesota Historical Society, The Kensington Rune Stone: Preliminary Report to the Minnesota Historical Society (St. Paul, 1915); and "The Story of the Kensington Runestone," a pamphlet printed by the Alexandria, Minnesota Chamber of Commerce (n.d.), MHS. Turner's views can be found in his letter to Gisle Bothne, 10 Feb. 1910, Gisle Bothne Papers, MHS.

54. Holand, Norse Discoveries and Explorations in America, 982-1362, p. 188. 
Indeed, with the obvious exception of Julius Olson's contribution to The Northmen, Columbus, and Cabot, twentieth-century texts in the Viking corpus tended to shy away from translation in favor of originality. Although this decision probably enhanced the popularity of the genre, it was a crucial mistake as a political strategy. For in asking readers to believe that the Vikings had penetrated the interior of the North American continent, Holand and others who deviated from translation abandoned not only standard explanations of American history but the very sources of authority that had allowed Anderson to credibly demand that readers make such a departure.

What this abandonment suggests is that Holand and other twentiethcentury authors failed to appreciate the key element that had sustained Anderson's nineteenth-century Viking narrative: its ability to negotiate a canny bargain between immigrants and the native born and, more specifically, its careful doubling, what Homi Bhabha has described as "the continuist, accumulative temporality of the pedagogical, and the repetitious, recursive strategy of the performative." ${ }^{55}$ As a nontranslation, Holand's text lost three important sources of authority on which Anderson's had drawn. First, the text departed from the long line of saga translations that flooded the English-speaking world in the nineteenth century, thus losing the authority of Beamish, Morris, Slafter, and its progenitors. Second, it lost the sedimentary weight of the sagas themselves, the "ancient manuscripts" that Slafter's map accepted and whose own origins resided in the depths of oral tradition. Third, Holand's decision to chart a new course for the Vikings deprived him of one of the key sources of credibility that immigrants do have in cultures that receive them: that of speakers and translators of their “own" languages and literatures. Significantly, Anderson's volume was able to capitalize on his authority as both a native speaker of Norwegian and a professional translator of the Norse languages, while at the same time effacing his performative role as a producer of an agonistic narrative of immigrant nationalism. As Lawrence Venuti has proposed more generally regarding translations "that have achieved mass circulation," in this context Anderson's discovery translation was able to become "the site of unexpected groupings, fostering communities of readers who would otherwise be separated by cultural differences and social divisions yet [we] re now joined by a common fascination," even though "the forms of reception" that these readers employed were "not ... entirely commensurable." ${ }^{66}$ Separated by class, ethnicity, and region, Anderson's readers were nonetheless joined by

55. Homi Bhabha, "DissemiNation: Time, Narrative, and the Margins of the Modern Nation," The Location of Culture (New York, 1994), p. 145.

56. Lawrence Venuti, “Translation, Community, Utopia," in The Translation Studies Reader, ed. Venuti (London, 2000), p. 477. 
the translated text. Without this bond (and without the comfort of Anderson's institutional location), Anderson's fragile reading community could not persist. Holand's work thus splintered the once unified constituencies of western immigrants and eastern Brahmins.

Holand's failure to appreciate the importance of compromise can be seen in another element of his work. Not only did his text discard translation as a model for immigrant writing, but it also introduced a new geography of discovery that too obviously rejected Brahmin hierarchies. Instead, Holand proposed an aggressive regionalism that privileged the upper Midwest, home to so many of his fellow Norwegian and other Scandinavian Americans. Brushing aside the eastern voyages of Leif Erikson and his contemporaries, Holand devoted not only Norse Discoveries but the better part of his adult life to proving how, through a complicated Arctic route, the Vikings had been able to leave the Kensington Stone in the geographical heart of the North American continent. ${ }^{57}$ This choice reflected the emergence of a growing regional immigrant popular culture that continues to thrive to this day. ${ }^{58}$ On a nice summer day it is not hard to find true believers at the Kensington Stone museum and site. Indeed, as Michael Michlovic and Michael Hughey have argued, Minnesota has been able to develop an entire tourism network based on the Viking appeal; the Minnesota Historical Society, moreover, is regularly besieged by letters and missives demanding to know why, as the official representative of the state's history, it has not embraced the authenticity of Minnesota's Viking heritage. ${ }^{59}$

57. The Arctic-route theory was also developed by others who wished to prove Viking landfall in Minnesota, such as Andrew Fossum, author of The Norse Discovery of America (Minneapolis, 1918) and "The Route from Vinland to Minnesota in 1362," unpublished ms., Andrew Fossum papers, NAHA. The debate over the location of the Vikings' travels and Vinland in particular is almost as voluminous as Viking discovery literature itself. It is thoroughly discussed in Kaups, "Shifting Vinland-Tradition and Myth." A few examples of efforts to locate Vinland include W. A. Munn, Wineland Voyages: Location of Helluland, Markland, and Vinland (St. John's, Nfld., n.d.); Anderson, Where Was Vinland? A Reply to Prof. Gustav Storm Refuting His Arguments in Favor of Locating Vinland (Minneapolis, 1891); Olson, Review of the Problem of the Northmen and the Site of Norumbega (Chicago, 189o); and A.D. Fraser, "The Norsemen in Canada," Dalhousie Review 27 (1937): 175-86.

58. A few examples of the Kensington Stone's penetration into the local popular culture include Margaret Leuthner, Mystery of the Runestone (Alexandria, Minn., 1962), a comic book for children Bert Merling, "The Runestone Pageant Play," unpublished ms., 1962, MHS, 1962; and "Runestone Festival Commemorating the 6ooth Anniversary of the Kensington Runestone," festival program, MHS. For a few brief examinations of the cultural significance of the stone, see Iver Kjær, "Runes and Immigrants in America: The Kensington Stone, the World's Columbian Exposition, and Nordic Identity," The Nordic Roundtable Papers 17 (July 1994): 7-31, and Michael G. Michlovic and Michael W. Hughey, "Norse Blood and Indian Character: Content, Context, and Transformation of Popular Mythology," Journal of Ethnic Studies 10 (1982): 79-94.

59. See Michlovic and Hughey, "'Making' History: The Vikings in the American Heartland," Politics, Culture, and Society 2 (Spring 1989): 338-60; see also Rhoda Gilman and James P. Smith, "Vikings in Minnesota: A Controversial Legacy," Roots 21 (Spring 1993). Correspondence demanding official recognition of the Kensington Stone is in possession of Debbie Miller, MHS. 
Nonetheless, despite the occasional seepage of runes and rune-chasing into the wider popular culture (fig. 6), it is difficult to find many people of non-Minnesotan, non-Scandinavian heritage who are deeply engaged with the Viking debate as history. Quite simply, it has become a curiosity of regional and immigrant culture. ${ }^{60}$ Unlike Anderson's comfortably colonial plotting of Viking discovery, Holand's map presented the less representative and less represented terrain between the Great Lakes and the Arcticterrain that, unlike Cape Cod, would not have been immediately recognisable as a stand-alone geography-as the new center of it all (fig. 7). Holand's work therefore asked Americans not only to accept a new version of their history, but a jarringly new cultural geography, as well. Even leaving aside the issue of its believability, Holand's Arctic map challenged, rather than conformed to, the "normal" geography of American discovery and demanded that Americans create a new mental map of the American past. All in all, it was too much to ask.

\section{A Canadian Coda}

This was not the Vikings' final North American hurrah, however (fig. 8). Although by midcentury the Norsemen had reverted to an ironically popular obscurity in the United States, they did make another, more fleeting appearance upon the stage of national history, this time in 1960 s Canada. Of course, 1960 . Canada was a completely different world than 1870 s America. Canadians had their own men in leaky boats to remember and two divergent and competing sets of discovering ancestors. More than that, by the 1960 s it was no longer so fashionable to cast national origins in racialized, teleological tones. Or was it? Consider the similarities between $1870 \mathrm{~s}$ America and 1960s Canada. For each nation, these were times of rapid economic, political, and geographical expansion. They were points at which the nations stood on the brink of massive demographic change. For both nations, these were times of self-conscious historical reflection and political redefinition, not only because they marked the nations' respective centennials, but because each nation's one hundredth anniversary was preceded and shaped by significant challenges to national sovereignty. And for both nations these were periods of expansion in the public higher education sector; while the Morrill Act of 1862 set the stage for massive academic growth and for greater student and faculty diversity in the years after the Civil War, so too did Canada's ambitious program of university building and deprivatization in the 1960s. Consider as well the similarities between Norwegian Americans in the 1870 s and Icelandic Canadians in the 1960 s.

60. Indeed, that is exactly the angle pursued in one of the longest press articles to arise from the show: Mark K. Stengel, “The Diffusionists Have Landed,” Atlantic Monthly 285 (Jan. 2000): 35-48. 


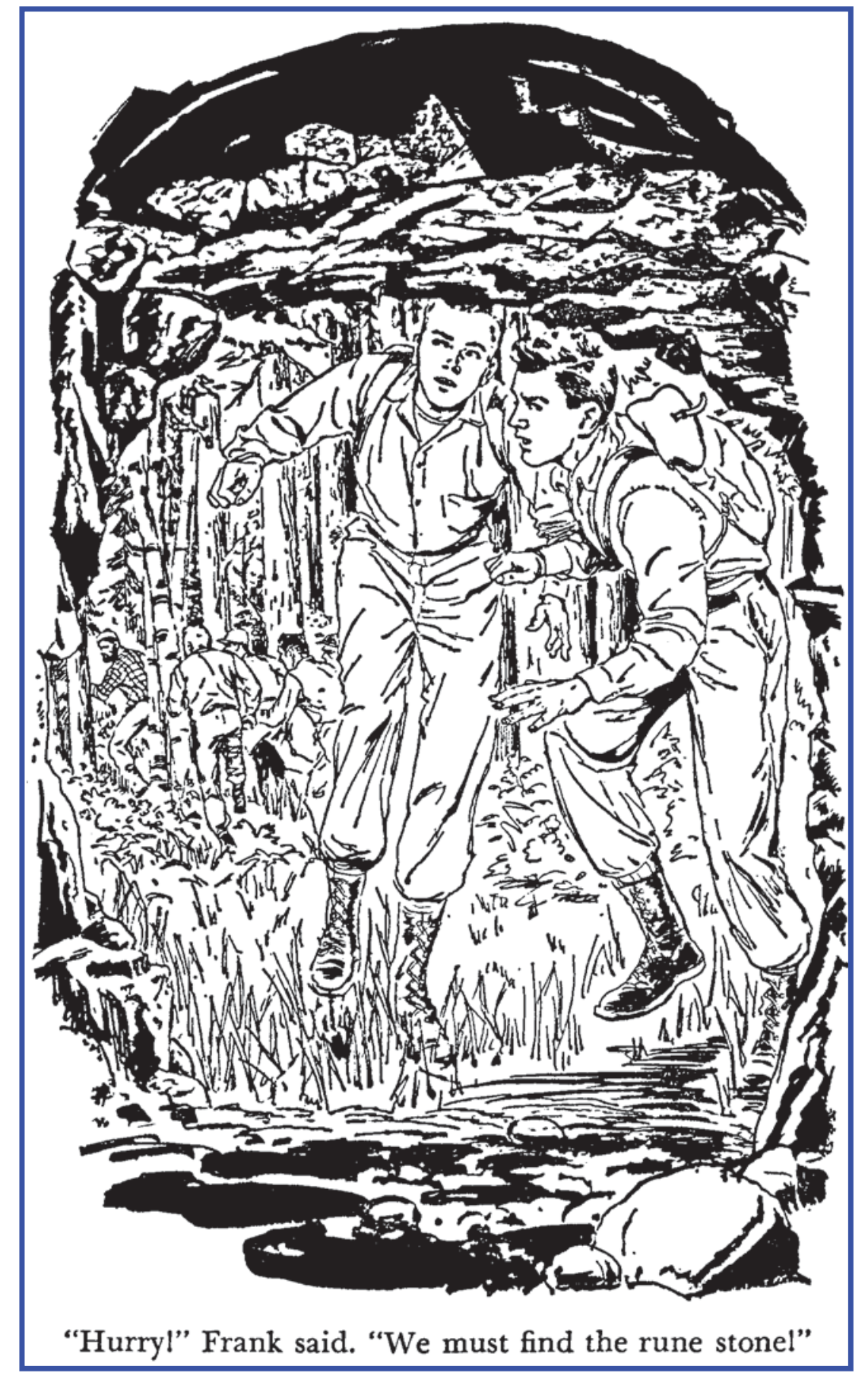




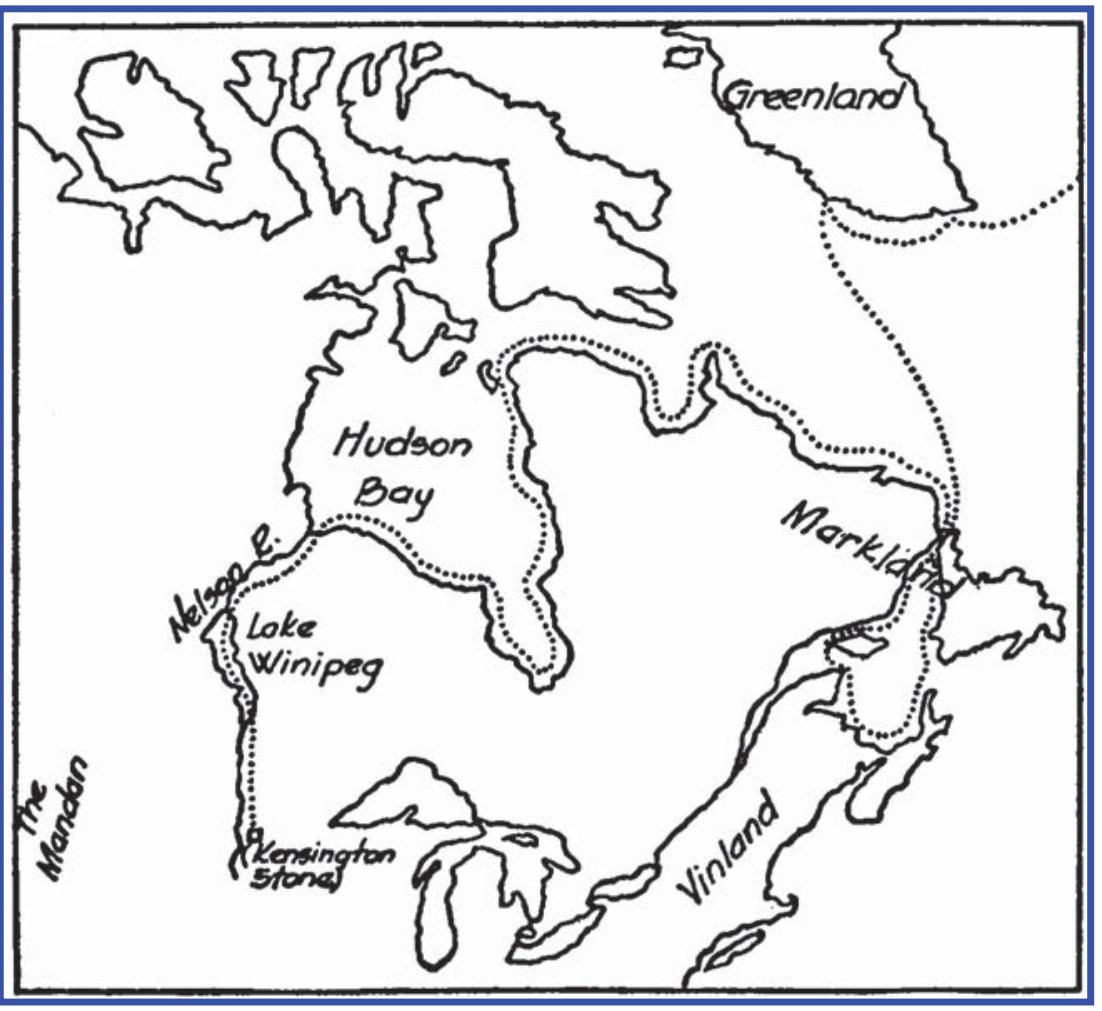

F I G U R E 7. "Sketch Showing Route by Way of Hudson Bay," from Hjalmar R. Holand, Norse Discoveries and Explorations 982-1362, p. 141.

During these two periods, each group was experiencing a moment when Old World tongues were giving way to English (a situation that was particularly acute for Icelandic Canadians in the wake of the Second World War); when elite members were emerging within the educational and professional hierarchy of the nonimmigrant community; when, in short, identities were in flux and deals could be struck.

It is perhaps unsurprising, then, that the Viking cause was resurrected at exactly this point, in Tryggvi J. Oleson's 1963 Early Voyages and Northern Approaches, $1000-1632 .{ }^{61}$ As the first volume in the series that defined academic history in 1960 s Canada, W. L. Morton and D. G. Creighton's Canadian Centenary series, Oleson's work gained the imprimatur of both the historical profession and academic publishing. It was also a significant work of immigrant historiography. For, just as Anderson had identified history as a suitable vector for the improvement of his group's status in the New World, so too did Oleson, who was a professor of history at the University 


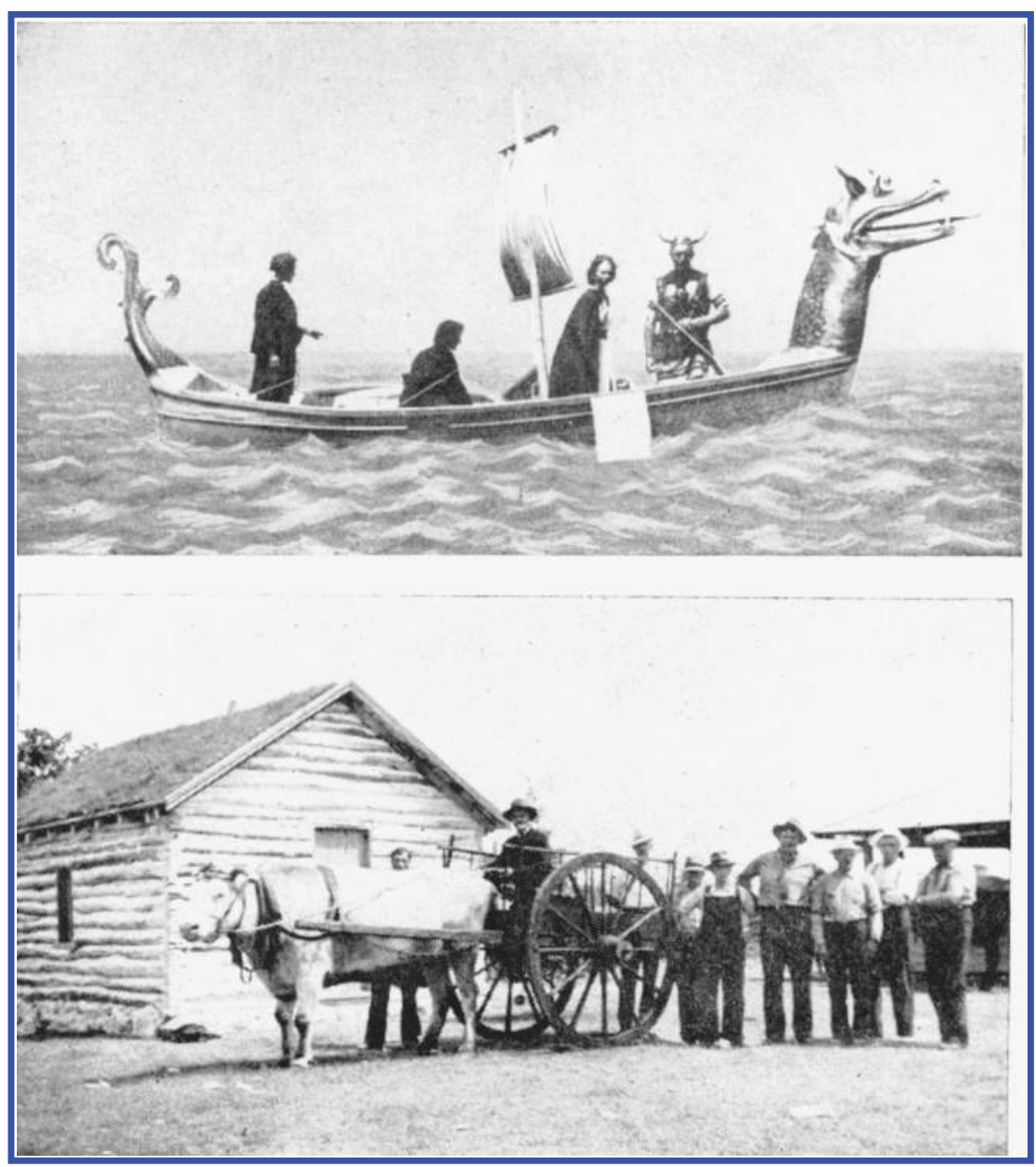

F I G U R E 8. "A Viking ship and a Red River Cart, sometimes used for transportation in the early days." From Lundar Diamond Jubilee (Lundar, Manitoba, 1948).

of Manitoba. ${ }^{62}$ As a founding officer of the Icelandic Canadian Club (begun in 1938 to promote knowledge of the Icelandic heritage in Canada), a former vice president of the Icelandic National League, and a member of a department whose honors students had names like Douglas, Gadadhar, Karpiak, Kung, Moore, Parasiuk, Salzberg, and Wagschal, but were very seldom of obvious Icelandic descent, Oleson embarked on this project not only as an academic historian but as an Icelandic Canadian. ${ }^{63}$

62. On Oleson, see W. J. Lindal, The Icelanders in Canada (Ottawa, 1967), pp. 298-99.

63. See “Arts IIIH," 16 May 1963, box 2, collection A95-26, department of history, University of Manitoba, Department of Archives and Special Collections, Elizabeth Dafoe Library, University of Manitoba (EDL-UM). 


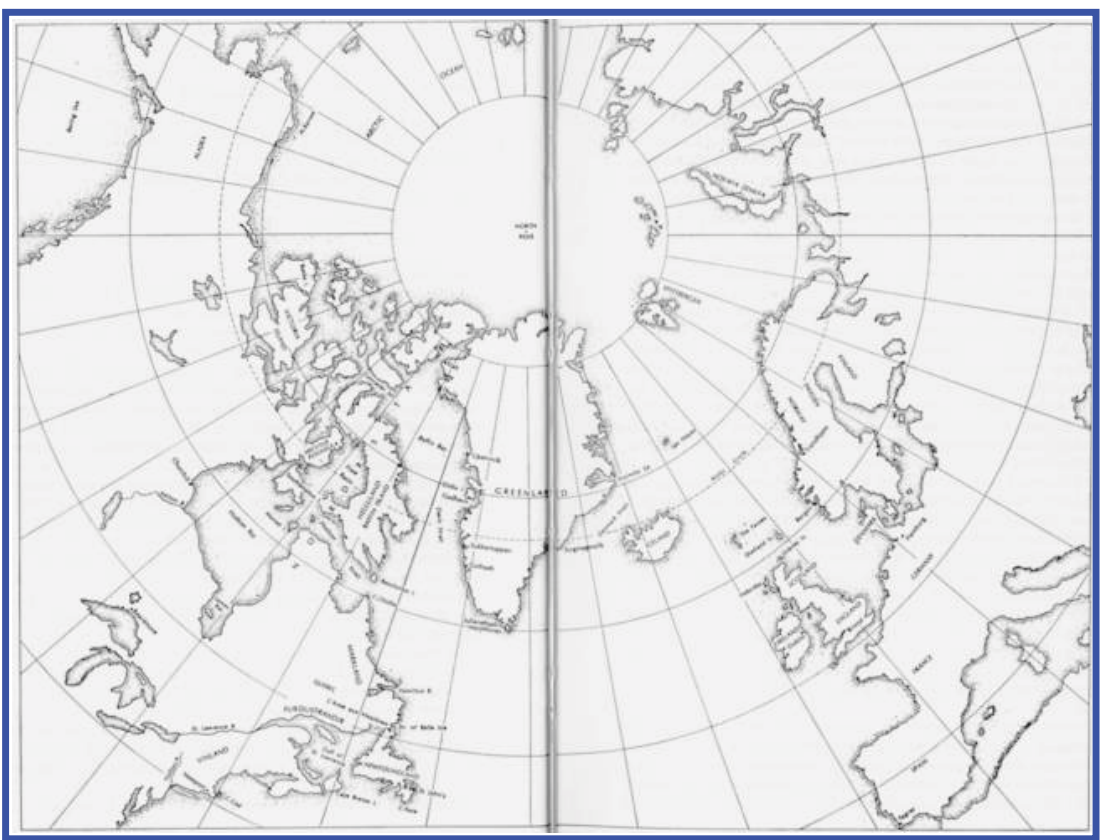

F I G U R E 9. From Tryggvi J. Oleson, Early Voyages and Northern Approaches, 1000-1632, pp. 2-3.

Oleson's project was also similar to Anderson's work in another respect. Just as Anderson had chosen the imagined Teutonic past as a fertile ground for compromise between Norwegians and nineteenth-century New Englanders, Oleson too chose compromise as his strategy, setting his narrative in terms that would appeal to mid-twentieth-century Canadian elites. ${ }^{64}$ Most importantly, Oleson appealed to Canadians' ongoing fascination with the North, proposing a theory of Viking exploration that recast the discovery of America as the discovery of the Canadian Arctic. ${ }^{65}$ From the very first illustration of his book (fig. 9), a map that cast Arctic Canada as the virtual center of the world, Oleson offered the North not only as the cornerstone of Canada's past but as the key to its future.

64. Although Oleson did not claim Anderson as an influence, he was known to the Icelandic community in Manitoba in his own lifetime through its first newspaper, Framfari. See untitled item, Framfari, 28 Mar. 1878. The entire run of the newspaper has been translated into English by George Houser in one volume (Winnipeg, 1986). The item on Anderson appears on p. 168.

65. The classic essay on the North in Canadian political consciousness is Carl Berger, "The True North Strong and Free," in Nationalism in Canada, ed. Peter Russell (Toronto, 1966), pp. 3-26. Visual imagery was used frequently as a tool in the formation of Canadian national identity as a "Northern" phenomenon. For an interesting analysis that links this process to similar issues in Scandinavia, see Roald Nasgaard, The Mystic North: Symbolist Landscape Painting in Northern Europe and North America, 1890-1940 (Toronto, 1984). More generally, see Thomas H. B. Symons, "The Arctic and Canadian Culture," in A Century of Canada's Arctic Islands, 1880-1980, ed. Morris Zaslow (Ottawa, 1980), pp. 319-37. 
In choosing the North as the geographical and historical center of his treatise, Oleson reached out to two significant Canadian elites. First, he provided historical support to his fellow academics, then engaged in a growing effort to define the Canadian identity. Indeed, Oleson's colleague and the coeditor of the Centenary series, W. L. Morton, had published a highly influential work entitled The Canadian Identity in 1961. Like other historical works of the time, this volume identified the North as the key to Canada's pressing need to "achieve a self-definition of greater clarity and more ringing tone than it has yet done." Following an imperative that had lurked in Canadian historiography at least since C. P. Stacey's The Undefended Border: Myth and Reality, booklet \#1 in the Canadian Historical Association's famous series of orange-covered primers, Morton argued that historians could provide a crucial service to Canada by distinguishing its development, and particularly its origins, from the United States. Somewhat ironically, then, as the book was written while Morton was Visiting Commonwealth Professor at the University of Wisconsin, Morton described (Canadian) Northerners as "a new breed of man" and offered readers a distinct paradigm of discovery that emphasized not only the familiar forays of John Cabot and others but included a nod to the less well-studied voyages of the "Viking frontiersmen" who opened the northern reaches of the New World to the English and the French. ${ }^{66}$

Oleson's work answered Morton's call for an exceptionalist Canadian history. Arguing that medieval Icelandic settlers in Greenland (following the same "natural" westward movement ascribed to Scandinavians by Holand and others) had moved from Greenland to Baffin Island and Labrador, Oleson provided Canadians with an alternative history to both the Columbian conquest and American accounts of Viking discovery. Although Oleson did not deny the possibility of Viking's landing in New England, he argued that their only certifiable New World landfall was not in Massachusetts, but in Canada. In Oleson's account, then, these voyages formed the prehistory, not of Puritan America, but of the Canadian Arctic. Describing the period of Icelandic discovery and contact as "the mediæval phase of Canadian history," Oleson implied that "Canada" preceded "America," ${ }^{67}$ thus offering bold support to Morton's assertion that "Canadian history is not a parody of American, as Canada is not a second-rate United States." ${ }^{68}$ Like Anderson's work, Oleson's treatise thus used native-stock historians' own agendas to further his own. While this version of Canadian history sup-

66. W. L. Morton, The Canadian Identity (Madison, Wis., 1961), pp. x, vii, 92. See also "Annual Report of the Department of History, 1959-1960," “Annual Reports" file, box 1, collection A95-26, department of history, University of Manitoba, EDL-UM.

67. Oleson, Early Voyages and Northern Approaches, 1000-1632, p. 63

68. Morton, The Canadian Identity, p. 93. 
ported wider appeals for a separate identity for Canada, it placed Icelandic Canadians at the very center of the social order as the descendants of the people who literally had put Canada on the map.

Indeed, Lyle Dick's very interesting recent work on the Centenary series suggests that the publication of Oleson's work in the series was directly attributable to its support of Morton's vision of both Canadian identity and academic history's role in realizing it. ${ }^{69}$ Not only did the series, and the works contained within it, support Morton's desire to combat, as Dick puts it, the "advancing American cultural juggernaut [that] spelled a diminished role for Canada's writers, including historians, in the Canadian body politic" ("GN," p. 251), but Oleson's volume in particular proved to Morton "the existence of the northern seaway for almost five hundred years before Columbus. I find this of significance both for the history of the latter discovery and for the nature of Canadian ties to Europe. It has not been accidental that we have not separated from Europe, as has the United States, and Latin America" (quoted in "GN," p. 234).

In Dick's view, this was significant for two reasons. First, as I have suggested, it provided Morton with evidence of Canadian exceptionalism in the Americas. More than that, however, Dick argues that this formulation also offered epic history as a solution to the brewing separatist conflict in Quebec. As Dick argues, “in Morton's mind there were integral connections between early Viking approaches to northern North America, its subsequent colonization by French and British settlers, and the incorporation of First Peoples into the eventual country of Canada." Thus Morton selected volumes, like Oleson's, that enhanced his vision of Canadian history "as a logical, even inevitable, progression to the modern nation-state," and "rejected topics he considered incompatible with his principal leitmotives of French-English duality and integration of the regions" ("GN," pp. 234, 235).

Dick concludes that this vision of Canadian history as the epic prefiguring of the nation-state led to Morton's marginalization of "alternative national aspirations, the history of Aboriginal peoples, or other groups or regions that did not fit in with its emphasis on Anglo-French duality within the Canadian nation-state" ("GN," p. 237). In general, I would agree with this assessment. Regarding immigrants, however, whom Dick does not specifically mention, I would make a further argument. Within the context of Morton's epic history, immigrants could make claims to Canadian identity. However, they could only do so effectively when those claims supported Morton's (and, because of Morton's influence, the historical profession's)

69. See Lyle Dick, “'A Growing Necessity for Canada’: W. L. Morton’s Centenary Series and the Forms of National History, 1955-80," Canadian Historical Review 82 (June 2001): 223-52; hereafter abbreviated "GN." 
wider agenda. For Oleson (as for Anderson), then, who was deeply committed to his own success (and the success of the Icelanders) within academic discourse, this meant that the only way to make Icelanders fit was to figure them as forefathers in a master narrative whose endpoint was the predetermined coming together of the British and the French in an integrated, Europe-linked nation-state. Because of the twin threats of Quebec nationalism and the "American juggernaut," mainstream academic history in the early 1960 s was only prepared for a theory of Canadian ethnic identity that supported the dually racial, yet nonetheless racialized epic of FrenchEnglish synthesis. ${ }^{70}$ Thus, for an immigrant historian like Oleson with aspirations towards the academic elite, ${ }^{71}$ multiculturalism was simply not an option. $^{72}$

There was also a more pragmatic element to Oleson's appeal. For while Morton worried, as Dick shows, about America, about biculturalism, "the

70. Interestingly, the French also occasionally conceived of themselves as Viking descendants ("Normans," of course), using this claim to shore up the more common claim of the French to Canadian discovery. In his Les Vikings des grandes étapes, vol. 1 of Les Northmans en Amérique (Montreal, 1954), Eugène Achard emphasized the common racial ancestry of French Canadians and the Vikings, writing that "Canadiens-français ou Anglo-Canadiens, nous sommes les rameaux détachés d'une même race: la race normande, et, par le fait même, les frères de ces hardis Northmans qui sillonnèrent les mers du nord et, vers l'an mille, vinrent planter leurs tentes en Amérique" (p. 28).

71. It is important to recognize that Oleson was, in fact, very successful as an academic. Not only did he publish Early Voyages and Northern Approaches, 1000-1632 alongside Canadian historiography's rising elite, but in the eleven years following his receipt of the Ph.D. in 1950 he was the beneficiary of numerous prestigious grants, including "a research grant of $\$ 6000.00$ by the Social Science Research Council of America," a Guggenheim Fellowship, three grants from the Ministry of Education in Iceland, a Nuffield Travel Grant, and a grant from the Canadian Social Science Research Council. He was also elected Fellow of the Royal Society of Canada in 1959 (Annual Report of the Department of History, 1960-1961," "Annual Reports" file, box 1, collection A95-26, department of history, University of Manitoba, EDL-UM; see also "Curriculum Vitae: Tryggvi Julius Oleson," 8 Dec. 1960, UA 20 004-047, EDL-UM).

72. It is important to note that, outside academia, this was not necessarily the case. Although Oleson pitched his vision of Icelandic-Canadian identity in terms that meshed with prevailing academic discourse, other Icelandic-Canadian authors aligned themselves with different discourses, with very interesting results. Most notably, Winnipeg judge and amateur historian W. J. Lindal, who was a vocal supporter of the chair of Icelandic language and literature at the University of Manitoba (1951) and the author of both The Saskatchewan Icelanders: A Strand of the Canadian Fabric (Winnipeg, 1955) and The Icelanders in Canada offered one of the most important alternative visions of Icelandic-Canadian identity to that proposed by Oleson. Drawing on the many local histories of the Icelandic communities in Manitoba, which in the tradition of Framfari, emphasized the Icelanders' compatibility rather than their competition with the "valiant" Sitting Bull and later populations of Ukrainians, Poles, and other immigrants, and drawing also on his firm conviction that Canada's ethnic diversity was the key to resisting totalitarianism, Lindal's work is characterized by a strong multicultural aspect. While Oleson's narrative emphasizes the inevitability (and danger) of racial fusion and the hegemony of certain strictly limited racial categories, Lindal's vision promotes a much more fluid notion of both ethnicity and of identity. Thus Lindal's work, which foreshadows the ascendance of multiculturalism as perhaps the 
even more hideous monster of "multiculturalism," and the role history could play in fashioning the Canadian nation, his relationship with Oleson was forged within another context: the rapid expansion of Canadian higher education ("GN," p. 243). For these were boom times. Between 1958 and 1964 , student numbers in the department of history increased from 312 to 850; within Manitoba as a whole, full-time college and university enrollment between 1957 and 1967 jumped from 4,870 to $12,400 .{ }^{73} \mathrm{As}$ a result, this period saw not only the expansion of existing departments at the University of Manitoba but the emergence of entirely new ones like the department of anthropology and sociology, established in 1962, and the Northern Studies Committee, founded in the same year with Morton as chair. ${ }^{74}$

Morton, who was the head of the history department during this entire period, seems immediately to have realized that this expansion could work to the benefit of his department and his discipline and that Oleson could be an important ally in history's ascent. Indeed, Oleson proved to be a valuable pointman not only on seemingly mundane, local issues like library funding - with Oleson as his spokesman, Morton managed to increase the department's library allocation five-fold between 1957 and 1961, to \$5,200, which gave it the biggest budget in the faculty_-but in a more global sense. ${ }^{75}$ For if the North offered a point of reentry for historians into the wider political culture, it could also provide something equally important: cold, hard cash. The fruits of expansion had to be divided up somehow, and

defining element of Canadian identity discourse since the 1970s, shows that "popular" immigrant historiography does not have to either take its cues from academic writing or to consist in a watered-down version of it. Indeed, unlike Holand's tract, which in relationship to Anderson's work marked the marginalization of the Viking narratives from mainstream discourse, Lindal's work (and the local histories it drew upon) may hold an important key to the popular origins of Canadian multiculturalism. See "News of the Indians," Framfari, 28 Mar. 1878, p. 171. For Lindal's views on totalitarianism, see his Two Ways of Life: Freedom or Tyranny (Toronto, 1940).

73. Departmental enrollments are from "Department of History: Annual Report, 1958-59"; "Annual Report of the Department of History, 1959-6o"; "Annual Report of the Department of History, 1960-1961"; "Department of History, 1961-62"; "Annual Report: Department of History, 1962-1963"; and "Annual Report: Department of History, 1963-1964," in "Annual Reports” file, box 1, collection A95-26, department of history, University of Manitoba, EDL-UM. Manitoba numbers are from the excerpt from "Universities and Colleges," Manitoba Economic Consultative Board 5th Annual Report (1967), table C-1, in "University in Community" file, box 4, collection A95-26, department of history, University of Manitoba, EDL-UM.

74. See Richard E. Bennett et al., A Guide to Major Holdings of the Department of Archives and Special Collections (Winnipeg, 1993), p. 102; "Northern Studies Committee," box 1, folder 1, mms. 41, Northern Studies Committee, EDL-UM; and G. W. Leckie, letter to Northern Studies Committee Planning Sub-Committee, 7 May 1971, in "Northern Studies" file, box 3, collection A95-26, department of history, University of Manitoba, EDL-UM.

75. See Oleson, letter to Elizabeth Dafoe, 20 Oct. 1959; David W. Foley, letter to Morton, 2 Apr. 1962; Morton, letter to Foley, 14 Oct. 1961; and Dafoe, letter to history department, 15 Apr. 1957, in "Library-University of Manitoba" file, box 2, collection A95-26, department of history, University of Manitoba, EDL-UM. See also Morton, letter to dean of the Faculty of Arts and 
if departments and individuals could find a good argument on behalf of their particular field of expertise, they were more likely to gain support for their work. The North seems to have been just such a winner, as money was handed over for institution-building projects like the Northern Studies Committee and the Centre for Settlement Studies, which had a significant Northern component, ${ }^{76}$ and for a multitude of individual projects. Funded by the University of Manitoba, as well as government agencies like the Department of Indian Affairs and Northern Development, these initiatives offered excellent opportunities to faculty, with Northern Studies alone disbursing \$116,000 in aid between 1962 and 1970. ${ }^{77}$

And yet, as Morton certainly realized, expanding opportunities also meant increased competition. Indeed, while annual funding for Northern Studies increased by fifteen or twenty times in its first ten years, applications for funding would escalate one-hundred-fold in its first five. ${ }^{78}$ To get their slice of the pie, historians like Morton would have to jostle among scientists, geographers, their new colleagues in anthropology, ${ }^{79}$ and numerous others and thus had to make sure that their language could accomplish not only the lofty feat of building the nation but the more pragmatic task of writing successful grant applications. As both a persuasive theorist of the North and, like Morton himself, an experienced academic funding entrepreneur, Oleson was a natural ally. ${ }^{80}$ Indeed, Morton certainly planned on Oleson's help in his bid to put the history department at the center of the Northern nexus, including Oleson in his 1962 plans for a program in Northern Historical

Science, 12 Apr. 1957 and n.d., 1956, box 1, collection A95-26, department of history, University of Manitoba, EDL-UM.

76. Materials on this initiative, formed in 1967 to study "problems associated with human settlement" focusing on western and northern Canada, can be found in UA 33, EDL-UM.

77. "Northern Studies Committee," box 1, folder 1, mss. 41, Northern Studies Committee, EDL-UM. To put this sum in context, Morton's salary as head of the History Department was $\$ 8,700$ in $1957-58$, and Oleson's prestigious SSRC grant for 1961-62 was $\$ 6,000$. See W. J. Condo, letter to W. L. Morton, 22 Mar. 1957, in "President: History-Administration” file, box 3 , collection A95-26, department of history, EDL-UM, and "Annual Report of the Department of History, 1960-1961, “Annual Reports” file, box 1, collection A95-26, department of history, University of Manitoba, EDL-UM.

78. See "Application for Grant in Aid of Northern Research by a Northern Research Institute," signed by J. A. Hildes, 6 Jan. 1967, box 3, folder 2, mss. 41, Northern Studies Committee, EDL-UM; "Report of the Committee on Northern Studies-The University of Manitoba, Fiscal Year 196263," box 5, folder 1, mss. 41, Northern Studies Committee, EDL-UM; and "Grant Applications 1966," box 3, mss. 41, Northern Studies Committee, EDL-UM.

79. Who claimed, as opposed to sociologists, to be "the only professional group with training and residential experience among non-literate cultures" (Grant application signed by John H. Steinbring, 8 Dec. 1966, box 3, mss. 41, Northern Studies Committee, EDL-UM).

80. See "Annual Report of the Department of History, 1960-1961"; "Curriculum Vitae: Tryggvi Julius Oleson"; and Morton, letter to dean of the Faculty of Arts and Science, 12 Apr. 1957 and n.d., 1956. 
Studies that he hoped would eventually produce Ph.D.s. ${ }^{81}$ It is in this institutional context, then, as well as in the context of the historical discourse, that we also must read Morton's publication of Early Voyages and Northern Approaches. For while Oleson's narrative supported Morton's vision of the North as the founding region of an integrated, exceptionalist Canada, this vision itself supported Morton's more personal ambitions for history as a discipline, a profession, and a component of his own institution.

For Oleson, collaboration with Morton promised its own rewards: not only the tangible benefits of academic support but the ongoing opportunity to disseminate his views on Viking discovery (and Icelandic originality) to wider and wider audiences of students and readers. While he did not live to see its final results, dying prematurely at fifty-one in 1963, he died committed to this project; for as Morton wrote in Oleson's obituary, "in his last weeks with us, [...] he talked confidently of a book on the Vikings, [which] would have given a very different picture of those seafaring settlers and traders than do the histories of English and French scholars, derived from the chronicles of terrified monks." ${ }^{82}$ Had he lived, one can be certain that Oleson would have carried out this plan.

While his work seems mainly to have been directed at fellow historians, Oleson also undoubtedly recognized that there was a wider constituency for works that offered answers to questions of identity and that provided legitimization for Canadian claims to the North. During the 1950 and 1960 s politicians, like historians, seem continuously to have been asking "'ourselves when we say "I am a Canadian" what do we really mean," and historians' fetishization of the North matched a preoccupation with the region among the nation's political and bureaucratic elite. ${ }^{83}$ This is certainly true of John Diefenbaker, who represented the North as both "New Frontier" and "national consciousness" and who made northern development a major campaign issue in 1957 and 1958. For Diefenbaker, as for many others in Canada's political class, the North represented not only an economic and political bonanza but the mythical soul of Canada. As the former prime minister reflected in his autobiography, he had spent a boyhood dreaming

81. See "Faculty of Graduate Studies and Research proposed Course Changes for the 1962-63 Calendar," 2 Feb. 1962, "Calendar Material, New Course Proposals, Etc., 1957-1965," box 1, collection A95-26, department of history, EDL-UM.

82. W. L. Morton, “Tryggvi Oleson, Scholar,” Winnipeg Free Press, 7 Dec. 1963, file UA 20004 047, Office of the President, President's Original Files, EDL-UM.

83. The quote is from Vincent Massey, first Canadian-born governor general and "Honorary President of the Canadian Centenary Council," speaking at Carleton University Convocation, 24 May 1963. See "Awareness of Canada," program for a symposium held in Winnipeg, Oct. 1963, "Academic Year, Committee on Meetings and Reports" file, box 1, collection A95-26, department of history, University of Manitoba, EDL-UM. 
of the North Pole, looking to Vilhjálmur Stefánsson (who himself promoted a version of Viking discovery on which Oleson would draw and whom Morton personally visited in 1959) as a Canadian "hero." 84

Yet Canada's compelling need for the North was complicated by the fact that its sovereignty over its Arctic territory was not entirely certain. ${ }^{85}$ As the work of Frank James Tester and Peter Kulchyski has shown, the threatening cold war presence of significant numbers of American military personnel, combined with encroachments by foreign scientists and the lingering effects of a scramble for the Arctic that had left the region littered with the flags of a half a dozen nations, contributed to a feeling of insecurity that spawned a body of defensive Northern policies. Indeed, Tester and Kulchyski compellingly argue that disastrous efforts to relocate Inuit families into the far reaches of the high Arctic in the 1950s, which led to acute hardship and dislocation, were motivated as much by the desire to demonstrate a sovereign Canadian presence in the region as by the wish to promote Inuit wellbeing. ${ }^{86}$

At the same time that it proposed the Vikings as Canada's progenitors, Oleson's medieval history provided a remedy for this uncertainty and an intellectual justification for the policies that resulted from it on two levels. First, like Anderson's place-names, it circumvented the tangled web of nineteenthand twentieth-century discovery claims by suggesting that medieval Icelandic-Icelandic-Canadian - forays rendered this modern crazy quilt of island-naming and flag-planting a dead issue. Second, just as Anderson had offered the discovery of a "Viking" corpse as proof that the Norsemen had arrived and persisted in America, Oleson proposed his own body of evidence in the form of "white" Eskimos, suggesting that the best evidence for Viking discovery (and Canadian sovereignty) lay not in archaeology but genealogy. ${ }^{87}$ Denying that Canada's Viking discoverers had simply vanished, Oleson argued that they had fused with the original people of the New World Arctic — the Skraelings of the sagas—-whom he classified as the pre-

84. John G. Diefenbaker, One Canada: Memoir of the Right Honourable John G. Diefenbaker, 3 vols. (Toronto, 1976), 1:11-17, 83-85. Stefánsson's Viking theories are explained in My Life with the Eskimo (1913; New York, 1971). See also Morton, letter to H. H. Saunderson, 13 Apr. 1959, in

"President: History-Administration" file, box 3, collection A95-26, department of history, EDLUM. Incidentally, Morton also had contacts with the Minnesota Historical Society, attending their centenary celebrations in 1949; see A. H. S. Gillson, letter to Morton, 4 Oct. 1949, box 3, collection A95-26, department of history, EDL-UM.

85. On the strategic importance of the North in the twentieth century, see Shelagh D. Grant, Sovereignty or Security: Government Policy in the Canadian North, 1936-1950 (Vancouver, 1988), and Matthew D. Evenden, "Harold Innis, the Arctic Survey, and the Politics of Social Science during the Second World War," Canadian Historical Review 79 (Mar. 1998): 36-67.

86. See Frank James Tester and Peter Kulchyski, Tammarniit (Mistakes): Inuit Relocation in the Eastern Arctic, 1939-1963 (Vancouver, 1994), pp. 320-25.

87. See Oleson, Early Voyages and Northern Approaches, 1000-1632, chaps. 7-12. 
decessors of the First People met by later European explorers. ${ }^{88}$ Citing numerous accounts of encounters with "white" or "blond" Eskimos in the annals of European exploration, Oleson insisted that the only plausible explanation for the disappearance of the Vikings in the Western Hemisphere was that they had literally become part of the Aboriginal population. ${ }^{89} \mathrm{Al}-$ though it is clear that Oleson found race mixing distasteful—akin to death for the Vikings— he argued that it had been a blessing to the Inuit. This mixture of virile Icelanders and "dirty black dwarfs, some three feet in height," he argued, owed not only its European racial characteristics but all that was worthy of its culture, politics, and religion to its Nordic heritage, even going so far as to claim that "the coiffure of the Eskimos is Icelandic, going back to Germanic times." 90

Aside from the pure appeal of spurious race theory, by the 1960 s there were powerful political reasons for embracing such a position. Like his temporal claim of Viking “discovery," Oleson's genealogical argument justified Canada's claims to the North both by undercutting claims of rival European discoverers (who in his history had arrived in the Arctic too late to discover the Arctic or its true Others, meeting instead only a Viking rearguard) as well as the Inuit themselves (who were descended from Vikings, just like Oleson himself, and thus could be expected to share the bounty of Northern development with their southern cousins). At a time when the government needed the Inuit in the North to prove its sovereignty-yet their presence posed one of the few potential challenges to Diefenbaker's "uniquely Canadian dream" of emptying the North of its resources for the benefit of the settler population $-{ }^{91}$ the idea that the Inuit were no more Aboriginal than their immigrant neighbors to the south must have seemed appealing indeed.

Although it is not clear that Oleson's work had a direct impact on politicians, there is evidence that the historical community, at least, was satisfied with his very strange account. First, as we have seen, Oleson was able to win over the single most important arbiter of Canadian historical dis-

88. The prevailing view is that malnutrition, rather than amalgamation or extermination, spelled the end of the Viking colonies in what is now Canada and Greenland. See, for instance, Robert McGhee, “They Got Here First, But Why Didn't They Stay?” Canadian Geographic 108 (Aug.-Sept. 1988): 13-21, and David B. Quinn, North America from Earliest Discovery to First Settlements: The Norse Voyages to 1612 (New York, 1977), p. 35.

89. See Oleson, Early Voyages and Northern Approaches, 1000-1632, p. 76.

90. Oleson, Early Voyages and Northern Approaches, 1000-1632, pp. 81, 88.

91. A useful discussion of Northern development in the postwar period, as well as its impact on Aboriginal peoples, may be found in Peter Clancy, "Northwest Territories: Class Politics on the Northern Frontier," in The Provincial State: Politics in the Provinces and Territories, ed. Keith Brownsey and Michael Howlett (Mississauga, Ont., 1992), pp. 297-322. 
course at the time. At Oleson's untimely death in late 1963, Morton wrote admiringly that he had made "clear to the world of scholarship—and to the people of his own stock-all that the great folk-wandering of the Scandinavian peoples in the ninth and tenth centuries meant to Europe and to this continent in particular." 92 It is in fact quite possible, even, that Morton's own formulation of Northernness, as expressed in his Canadian Identity, was forged in his relationship with Oleson; after all, by the time Morton wrote that book, the two men had been colleagues and allies for ten years. ${ }^{93}$ Indeed, Oleson seems to have succeeded in planting the seeds of a minor Viking obsession in Morton's brain, evidenced not only by Morton's published and editorial work but by what leaked out onto the paperwork during dull departmental meetings (fig. 10).

Beyond personal influence, the publication of Early Voyages in Morton's series gained Oleson something else: long-term access to Canada's university libraries and to its students. Nearly forty years after Oleson's death, a perusal of one such library ${ }^{94}$ turned up no fewer than five copies of the book on the shelves. Perhaps more disturbingly, the narrative gained another, parallel set of lives when the Canadian Historical Association printed a condensed, but substantively similar version of his theory in its familiar, orange-covered primer series, as Historical Booklet $\#_{14}$, The Norsemen in America/Les Scandinaves en Amérique (figs. 11-12). ${ }^{95}$ This pamphlet, like other tracts in the series, was distributed throughout schools and universities, where it was quite improbably still in use in classrooms as late as the 1980 s (and may yet find its way today).

Thus, there is no doubt that Oleson's fantasy of disappearance, like Anderson's discovery narrative, was successful. Unlike most historical works, not to mention immigrant nationalist pedagogies, it cleared the gatekeepers who controlled access to academic publishing and reached at least two generations of students. In the end, this success suggests that those immigrant authors who succeeded in making the Vikings part of New World history succeeded precisely because of the compromises they made. Just as "the appropriation of a dominant language $[\ldots]$ and the shift of dominant poetics towards the standards of a minority or post-colonial people are potent means of realigning power structures in a shared cultural field and of asserting an independent world-view," Scandinavian-Americans' appropri-

92. Morton, "Tryggvi Oleson, Scholar."

93. See Morton, letter to the dean of the Faculty of Arts and Sciences, 18 May 1951, box 1, collection A95-26, EDL-UM.

94. Not the University of Manitoba.

95. See The Norsemen in Americal Les Scandinaves en Amérique (1963; Ottawa, 1970). 
At a meeting of the Sub-Committee Thursday, December 17th, 1962, the following recomendations were made for presentation to the Honours Committees

1. That the case of a student applying to enter Honours who has completed ten courses but not the prescribed ten may be considered by the Committee; that the case of a student who has completed nine courses and failed or lacks standing in one course outside of the subject of concentration will be considered by the Committee provided he has an average of at least $75 \%^{\circ}$ in the subject in which he plans to take honours and in subjects pertinent to this honours course.

2. That an honours student with one fatlure in an honours programme but otherwise qualified to proceed be given supplemental privilege and permitted to remain in the honours course; that a student with two such fallures in an honours year be considered by the Committee.

3. That a student who has fallures in an honours programme be allowed to repeat the year in honours if he so wishes and with the permission of the Head of the honours Department.

4. That the case of a student who has one failure not below $40 \%$ but otherwise an exceptionally good record may be considered by the Honours Committee with a view to raising his mark to a pass mark.

5. That a student reverting from the Honours to the General Course mast have passed the equivalent of two full courses in the April examinations in order to retain any credit for courses taken in his honours year or to recelve any supplementel privileges.

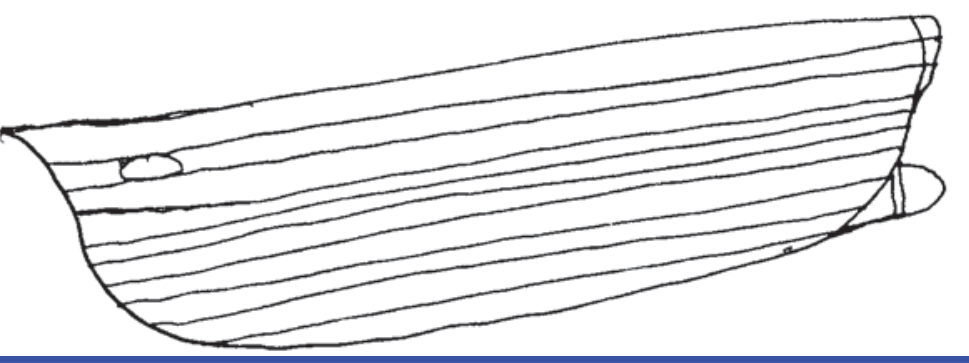

F I G U R E 10. W. L. Morton, "Sub-Committee of the Honours Committee," "Honours

Committee” file, box 2, coll. A95-26, EDL-UM. 


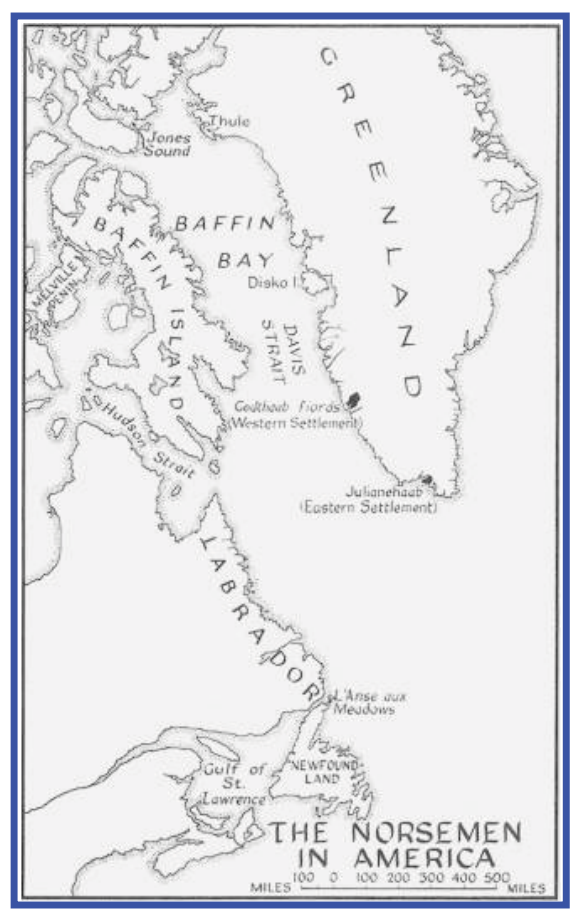

F I G U R E 11. “The Norsemen in America.” From The Norsemen in America, p. 23.

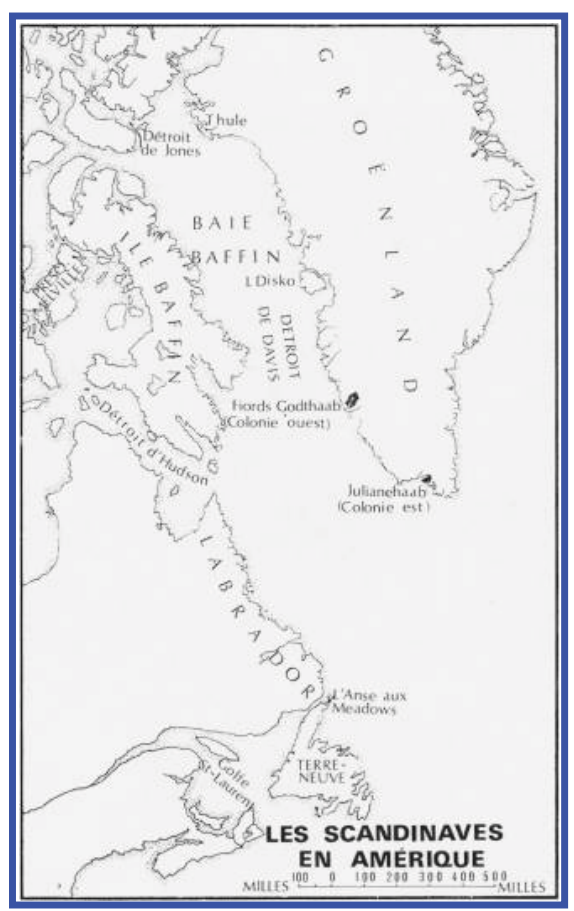

F I G U R E 12. "Les Scandinaves en Amérique." From Les Scandinaves en Amérique, p. 24.

ation of North American English as the language of immigrant literature and their shifting of a dominant pedagogy towards the standards of a minority marked a significant play for sovereignty. ${ }^{96}$ Although there were clear limits to this strategy, in significant ways both Anderson and Oleson found a successful way to negotiate the path between assimilation and resistance that leads to immigrant autonomy. 